Research papers

\title{
Characterizing wave- and current- induced bottom shear stress: U.S. middle Atlantic continental shelf
}

\author{
P. Soupy Dalyander ${ }^{\mathrm{a}, *}$, Bradford Butman ${ }^{\mathrm{a}}$, Christopher R. Sherwood ${ }^{\mathrm{a}}$, Richard P. Signell ${ }^{\mathrm{a}}$, \\ John L. Wilkin ${ }^{\text {b }}$ \\ a U.S. Geological Survey, 384 Woods Hole Road, Woods Hole, MA 02543, USA \\ ${ }^{\mathrm{b}}$ Rutgers University, 71 Dudley Road, New Brunswick, NJ 08901, USA
}

\section{A R T I C L E I N F O}

\section{Article history:}

Received 14 December 2011

Received in revised form

6 August 2012

Accepted 28 October 2012

Available online 5 November 2012

Keywords:

Bottom stress

Wave stress

Current stress

Sea floor disturbance

Middle Atlantic Bight

\begin{abstract}
A B S T R A C T
Waves and currents create bottom shear stress, a force at the seabed that influences sediment texture distribution, micro-topography, habitat, and anthropogenic use. This paper presents a methodology for assessing the magnitude, variability, and driving mechanisms of bottom stress and resultant sediment mobility on regional scales using numerical model output. The analysis was applied to the Middle Atlantic Bight (MAB), off the U.S. East Coast, and identified a tidally-dominated shallow region with relatively high stress southeast of Massachusetts over Nantucket Shoals, where sediment mobility thresholds are exceeded over 50\% of the time; a coastal band extending offshore to about $30 \mathrm{~m}$ water depth dominated by waves, where mobility occurs more than $20 \%$ of the time; and a quiescent low stress region southeast of Long Island, approximately coincident with an area of fine-grained sediments called the "Mud Patch". The regional high in stress and mobility over Nantucket Shoals supports the hypothesis that fine grain sediment winnowed away in this region maintains the Mud Patch to the southwest. The analysis identified waves as the driving mechanism for stress throughout most of the MAB, excluding Nantucket Shoals and sheltered coastal bays where tides dominate; however, the relative dominance of low-frequency events varied regionally, and increased southward toward Cape Hatteras. The correlation between wave stress and local wind stress was lowest in the central MAB, indicating a relatively high contribution of swell to bottom stress in this area, rather than locally generated waves. Accurate prediction of the wave energy spectrum was critical to produce good estimates of bottom shear stress, which was sensitive to energy in the long period waves.
\end{abstract}

Published by Elsevier Ltd.

\section{Introduction}

Seabed disturbance occurs as a result of bottom shear stress, the combined force waves and currents exert on the sea floor. Bottom shear stress suspends sediment; influences surface sediment texture and micro-topography; directly and indirectly impacts benthic organisms; dissipates wave and current energy; contributes to turbulence and mixing; and can influence placement or design of offshore structures. Despite the influence of bottom stress on the benthic environment, description and quantification of stress over regional scales have received little attention, in part because in situ observation can only be made at points and there is no robust standard measurement technique for bottom stress, especially in wavedominated environments (Sherwood et al., 2006). In previous regional studies, numerical model estimates of wave, mean current, and tidal forcing, each calculated independently, have been used, which would underestimate wave-current stress in areas where strong storm-

\footnotetext{
* Corresponding author. Tel.: +1 508457 2290; fax: +1 5084572310.

E-mail address: sdalyander@usgs.gov (P.S. Dalyander).
}

driven currents accompany large waves (Harris and Coleman, 1998; Hemer, 2006; Porter-Smith et al., 2004) and neglect the non-linear effects of wave-current interaction. The technological advancement of hydrodynamic and wave numerical models, and the computational ability to run the models over large areas for long time periods, allows concurrent estimates of waves and currents and calculation of combined wave-current stress. In the present study, a suite of numerical models was used to estimate time-series of bottom shear stress. A methodology was developed to characterize the magnitude and frequency of bottom shear stress and sediment mobility, and to identify the dominant physical forcing mechanisms driving stress distribution. The methodology was applied to characterize bed stress and sediment mobility over the entire continental shelf spanning the U.S. East Coast Middle Atlantic Bight.

\section{Study location characteristics}

The Middle Atlantic Bight (MAB) extends southwestward from Nantucket Shoals offshore of Massachusetts to Cape Hatteras, North Carolina (Fig. 1). The MAB continental shelf is about $100 \mathrm{~km}$ 


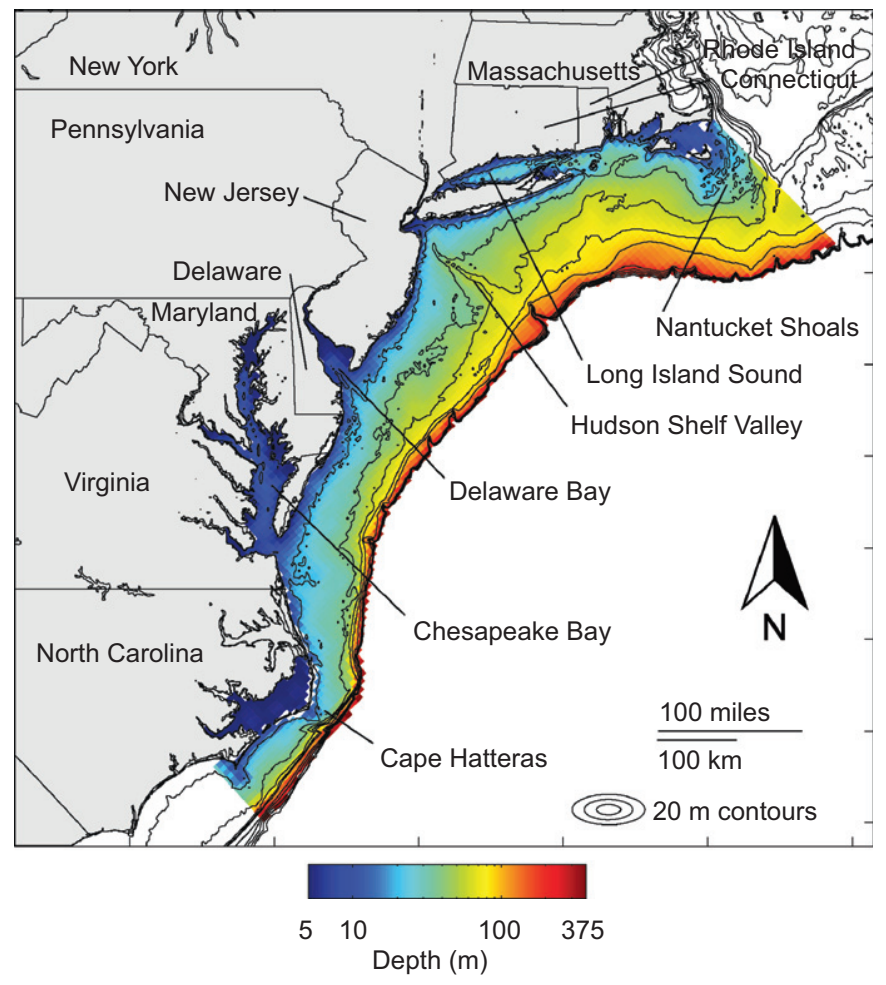

Fig. 1. Location of the Middle Atlantic Bight study area. Bathymetric contours are derived from the ETOPO2 data set (U.S. Department of Commerce, 2006).

wide at the northern end, narrowing to the south to approximately $40 \mathrm{~km}$ wide at Cape Hatteras (Lentz, 2008a). A predominant bathymetric feature is the Hudson Shelf Valley (HSV), an ancestral river valley of depth $25-40$ m below the adjacent shelf that bisects the MAB into northern and southern components (Butman et al., 2003b). Sediment texture is variable, but generally medium/coarse to fine sand at shallow depths with a transition to a mixture of silt and clay toward the shelf break (Fig. 2). Although the bulk of shelf sediments are sand dominated, west and southwest of Nantucket Shoals is the "Mud Patch" (Fig. 2), defined by greater than $25 \%$ mud (silt plus clay) and occupying a $100 \mathrm{~km}$ alongshelf and $50 \mathrm{~km}$ cross-shelf area in water depths between 55 and $65 \mathrm{~m}$ (Reid et al., 2005; Twichell et al., 1981). The Mud Patch formed in the last 10,000 years during rising sea level, and is hypothesized to be fine-grained sediment winnowed from glacial deposits on Georges Bank, transported westward in the residual mean flow, and deposited where the tidal currents decrease sharply (Bothner et al., 1981; Butman, 1987; Twichell et al., 1981). Throughout the MAB, a layer of unconsolidated finegrained material is occasionally observed atop the coarser grained sand (Butman et al., 1979).

The MAB is subject to occasional tropical storms during summer and higher frequency Nor'Easter storms in winter (Beardsley and Butman, 1974; Butman et al., 2008; Chang et al., 2001). During storm events, along shelf flows of up to $0.50 \mathrm{~m} / \mathrm{s}$ near the bed may occur, correlated to wind stress forcing (Butman et al., 1979; Keen and Glenn, 1995; Lentz, 2008b; Lyne et al., 1990a). During the summer, packets of internal waves have been observed at locations within the MAB at intervals of 3-25 h with energies on the order of $\mathrm{MJ} / \mathrm{m}$ (Shroyer et al., 2010), generating near-bottom currents with maximum speeds of $0.04-0.22 \mathrm{~m} / \mathrm{s}$ that may produce appreciable sediment resuspension (Butman et al., 1979; Churchill et al., 1994). M2 tidal currents exceed $0.50 \mathrm{~m} / \mathrm{s}$ over Nantucket Shoals, and are $0.10-0.15 \mathrm{~m} / \mathrm{s}$ throughout the rest of the MAB (Moody et al., 1984). More complete

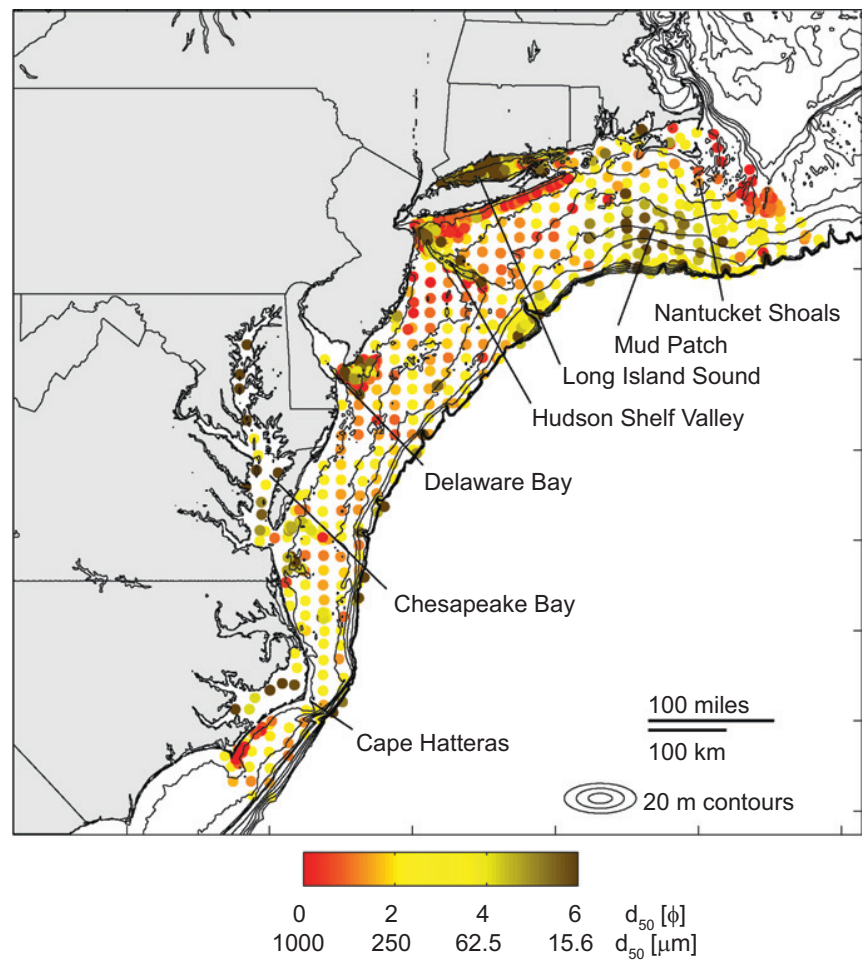

Fig. 2. Median sediment grain size (in phi and micron units) in the Middle Atlantic Bight from individual surface grab samples (data from U.S. Geological Survey East Coast Sediment Database (McMullen et al., 2011)).

descriptions of flow patterns in the MAB over the year and during specific types of meteorological events may be found elsewhere (Butman et al., 1979; Böhm et al., 2006; Chang et al., 2001; Csanady et al., 1988; Dzwonkowski et al., 2010; Harris et al., 2003; Keen and Glenn, 1995; Lentz, 2008a, 2008b; Madsen et al., 1993; Wright et al., 1994).

Near-bottom observations have shown episodic sediment movement in winter associated with winter storms (Butman et al., 1979; Churchill et al., 1994; Lyne et al., 1990a; Twichell et al., 1981) and in summer caused by high-frequency internal waves (Butman et al., 1979; Churchill et al., 1994) and tropical storms (Chang et al., 2001). Although the fine-grained Mud Patch deposit is more quiescent, surficial sediments there are occasionally resupended by winter storms (Twichell et al., 1981) or tropical cyclones (Chang et al., 2001).

A few studies have quantified bottom stress over weekly to monthly time scales at point locations in the MAB using observational wave and current data as input parameters to a bottom stress model. We used these studies where available to validate our modeling approach. Lyne et al. (1990a, 1990b) made stress and sediment transport estimates from near-bottom observations of waves and currents during the winters of 1978-1980 at two tripods within the Mud Patch (sediment texture at study sites consisting of $25-75 \%$ silt plus clay) at depths of $\sim 70 \mathrm{~m}$. Time series records of beam attenuation (an optical measurement inversely proportional to suspended sediment concentration) from Lyne et al. (1990a, 1990b) indicate that critical stress exceedance and resuspension only occur during storm events. Using near-bed current data from tripod deployments and wave spectra from National Data Buoy Center (NDBC) buoy 44008 , Chang et al. (2001) estimated the bottom stress at locations in and near the Mud Patch (silt plus clay content over 30\% at study sites) during the fall of 1996 for comparisons with beam attenuation data. They determined that the passage of hurricanes Edouard and Hortense resulted in combined wave-current stresses in 
excess of $0.35 \mathrm{~Pa}$ at a depth of $\sim 70 \mathrm{~m}$, and resuspension occurred at a critical stress of $0.08 \mathrm{~Pa}$. Churchill et al. (1994) estimated bottom stress at four sand-dominated (silt plus clay content of $1.1-1.6 \%)$ locations located across shelf in the mid-MAB at depths ranging from 40 to $130 \mathrm{~m}$, and determined the critical stress threshold for resuspension varied between 0.08 and $0.22 \mathrm{~Pa}$. In addition, Churchill et al. (1994) found that the contribution of wave stress to the overall stress decreased with increasing water depth. At $\sim 40 \mathrm{~m}$ depth, wave stress was the dominant forcing, while at $\sim 130 \mathrm{~m}$ wave stress was a minor contributor to the overall stress.

\section{Methodology}

Bottom shear stress estimates (Section 3.1) were made following Madsen (1994) from bottom orbital velocity and bottom wave periods generated by a Simulating WAves Nearshore (SWAN) model (Holthuijsen et al., 1993) and near-bed current estimates from a Regional Ocean Modeling System (ROMS) hydrodynamic model (Shchepetkin and McWilliams, 2005, 2009a). Wave model data were generated for this study as a one-year hindcast covering May 2010 to April 2011 (Section 3.2). The hydrodynamic data were from real-time Integrated Ocean Observing System (IOOS) forecast runs carried out by Rutgers University on the Experimental System for Predicting Shelf and Slope Optics (ESPreSSO) model domain (Section 3.3). Stress statistics were calculated over the period of May 2010-April 2011. Although a longer time record would allow more robust characterization of seasonal patterns and address interannual variability, at the time of this study additional years of ESPreSSO model computation had not been completed.

\subsection{Calculation of bottom shear stress}

A variety of models have been developed for predicting combined wave- and current-induced bottom shear stress (see Holmedal et al., 2003; Shi and Wang, 2008; Soulsby et al., 1993; and references therein). In this study, the Grant-Madsen (GM) formulation was used. This approach relies on an eddy viscosity turbulence closure model and formulates the wave stress (WS), current stress (CS), and combined wave-current bottom stress (WCS) as a function of a representative bottom wave orbital velocity $\left(u_{b r}\right)$, representative bottom wave period $\left(T_{b r}\right)$, current flow at some reference height, angle between wave and current propagation, and bottom roughness $\left(k_{b}\right)$. Full details of the GM formulation may be found elsewhere (Glenn, 1983; Glenn and Grant, 1987; Grant and Madsen, 1979, 1982, 1986; Madsen, 1994; Madsen et al., 1988).

Representative bottom orbital velocities and periods were calculated by SWAN (see Section 3.2) following Madsen et al. (1988) and output at hourly time steps. In the SWAN release available at the time of this study (version 40.81), an erroneous factor of $\sqrt{2}$ not present in prior releases had been introduced in the calculation of root-mean square velocity, $U_{\text {rms }}$, which is subsequently used to calculate the root-mean-square velocity amplitude $\left(u_{b r}\right)$ used in the GM formulation. The calculation was corrected within the source code to the prior, correct calculation of $U_{\mathrm{rms}}$.

The calculation of bottom representative period $\left(T_{b r}\right)$ in SWAN uses the Madsen et al. (1988) rather than the updated Madsen (1994) formulation. To determine the previously un-quantified impact of calculation method on computed wave stress, $u_{b r}$ and $T_{b r}$ using both the Madsen '88 and '94 formulations were calculated from observed spectra from National Data Buoy Center (NDBC) U.S. East Coast and Gulf of Mexico buoys for May, 2010 to April, 2011 (the one year period of the study). Wave conditions were sufficiently energetic to induce a non-zero bottom shear stress for a combined 154,621 h observations at 27 buoys in water depths ranging from 10 to $200 \mathrm{~m}$. The magnitude in difference between WS calculated using the Madsen ' 88 vs. Madsen '94 formulation was less than $0.01 \mathrm{~Pa}$ for $95 \%$ of the data points and less than $0.03 \mathrm{~Pa}$ for $99 \%$ of the data points. The change in WS as a percentage of WS using the Madsen ' 88 rather than the Madsen '94 formulation was less than 6\% for 95\% of observations and less than $10 \%$ for $99 \%$ of observations. Madsen (1994) noted that the effects calculation method produces negligible impacts on the wave-current interaction when compared to other uncertainties in the bottom boundary layer model.

The wave propagation direction used to calculate the angle between waves and currents for the Madsen (1994) stress calculations is the direction of propagation of the representative periodic wave $\left(\phi_{w r}\right)$, calculated from the near-bottom wave orbital velocity spectrum, which itself is a function of the surface spectrum for each frequency (described in Wibert and Sherwood, 2008 , and Soulsby, 1997). SWAN does not calculate the propagation direction of the representative periodic wave at the bottom. This calculation, a function of relative wave radian frequency $(\sigma)$, direction $(\theta)$, water depth $(d)$, and wave number $(k)$, was added within SWAN as

$\phi_{w r}=\tan ^{-1}\left(\frac{\int_{0}^{2 \pi} \int_{0}^{\infty} \sigma^{2} /\left(\sin h^{2}(k d)\right) \sin \theta d \sigma d \theta}{\int_{0}^{2 \pi} \int_{0}^{\infty} \sigma^{2} /\left(\sin h^{2}(k d)\right) \cos \theta d \sigma d \theta}\right)$

Using the mean surface wave direction would theoretically introduce error into the calculation of the angle between wave and current propagation at the bottom because of the frequency dependence of wave attenuation through the water column. Since this potential error had not been previously quantified, the WCS statistics for the MAB were calculated using both the bottom direction and the mean surface direction. The difference in yearly mean WCS varies spatially, with the largest changes in magnitude of order $0.05 \mathrm{~Pa}$ and $\pm 8-10 \%$ of the baseline values calculated using bottom wave direction.

Calculation of meaningful representative wave propagation direction requires that the directional spreading function is the same at all frequencies (Madsen, 1994). If multiple wave groups propagating in different directions induce orbital motion at the seabed, this assumption is invalid. As an example to quantify the potential error introduced by errors in the bottom wave direction calculation for multiple wave groups, for a bottom representative wave with a $u_{b r}$ of $0.25 \mathrm{~m} / \mathrm{s}$ and a $T_{b r}$ of $10 \mathrm{~s}$ in a current of $0.1 \mathrm{~m} / \mathrm{s}$ at $1 \mathrm{~m}$ above the bed with $k_{b}$ equal to $0.005 \mathrm{~m}$, the WCS will increase by $20 \%$ for a wave direction perpendicular to current flow over when the wave direction is parallel to current flow. In practical application on realistic coastlines, shielding by topography would limit the directions over which incidents waves can arrive, and those waves groups that interact with the bottom would begin to refract to orient along isobaths and thus be more in alignment with each other. This effect will reduce the angle between multiple stress-generating wave groups and limit the error introduced in calculating a single representative bottom direction.

Near-bed current magnitude and direction were obtained from the hydrodynamic model (see Section 3.3). Because the hydrodynamic model uses constant sigma layers in the vertical, the bottom grid cell height $\left(z_{R}\right.$, taken as the distance from the cell vertical midpoint to the seabed) varies over the domain. GM requires that the current velocity be taken above the wave boundary layer (WBL) but within the log-profile current velocity layer. During low-tide conditions at some shallow locations, the thickness of the WBL $\left(\delta_{\mathrm{wc}}\right)$ calculated using GM exceeded $z_{R}$ of one or more of the deepest grid cells; in these situations, 
the current estimate and associated reference height were used from the deepest grid cell at each location where $z_{R}$ exceeds $\delta_{\text {wc }}$.

Bottom stress can be estimated from modeled current only if the bottom cell is located in the region where the log-profile velocity layer assumption is valid. As discussed in Grant and Madsen (1986), the thickness of the log-profile layer based on laboratory experiments is approximately $10 \%$ of the current boundary layer thickness (Clauser, 1956). Because tidal currents, storm currents, and mean flow have a typical boundary layer thickness of order of magnitude 10's of meters (Goud, 1987), a maximum value for $z_{R}$ was set as $5 \mathrm{~m}$. This value may overestimate the thickness of the log layer in some flow conditions; in situ measurements of the near-bed profile have found some deviation from a log-profile at distances less than $5 \mathrm{~m}$ off the bed (Sanford and Lien, 1999; Friedrichs et al., 2000). The sensitivity of the stress characterization results to the choice of maximum $z_{R}$ was unknown; therefore, at locations where the vertical resolution of the model resulted in multiple grid cells meeting the criterion for minimum and maximum $z_{R}$, the WCS was calculated for the deepest cell above the WBL and for the shallowest cell with $z_{R}$ less than $5 \mathrm{~m}$. For the 1458 locations on the shelf where stress estimates could be made using current from multiple reference levels, the average difference between the mean WCS for the one year study period calculated using currents from the shallowest cell within $5 \mathrm{~m}$ of the bottom vs. the deepest cell above the WBL was $0.009 \mathrm{~Pa}$, with $99 \%$ of locations changing by less than $0.05 \mathrm{~Pa}$. The vertical resolution of the hydrodynamic model combined with a maximum $z_{R}$ of $5 \mathrm{~m}$ limits stress calculations to depths less than $\sim 130 \mathrm{~m}$.

The GM model requires a bottom roughness, which was problematic to establish over the model domain. Grain size information was not available at the $5-\mathrm{km}$ model grid resolution, and even if available, defining a single meaningful roughness at that scale would be non-physical because of the observed spatial variability (Churchill et al., 1994). The physical roughness used in GM stress calculations is the Nikuradse sand grain size $\left(k_{b}\right)$, equal to the sand grain size with the equivalent roughness of the seabed including contributions from bedform microtopography (Nikuradse, 1933; Madsen, 1994). Accounting for ripple formation and destruction is difficult, because relic bedforms not in equilibrium with flow conditions may persist following events. Bedforms may also be formed or destroyed through bioturbation or anthropogenic activity, such as trawling, and non-geological elements such as shell hash or submerged aquatic vegetation (SAV) will influence the roughness. There is also a contribution of near-bed sediment transport to the total bottom roughness (Glenn, 1983), which itself is difficult to compute due to the influence of stress history on sediment resuspension (e.g., bed armoring) and sediment advection from other locations. At point locations, bottom roughness has been estimated through direct observation (Lyne et al., 1990a, 1990b).

Because of the issues described above, it was not possible to make a spatially-resolved estimate of bottom roughness over the entire MAB; therefore, a uniform roughness was used, based on values from previous studies established using direct observations. Using photographic data from Lyne et al. (1990a, 1990b), Churchill et al. (1994) used a $\mathrm{k}_{\mathrm{b}}$ of $0.02 \mathrm{~m}$ as the mid-range of observed values during non-storm conditions of 0.005-0.05 m. During storm events, large increases and decreases in the bottom roughness can occur, with bedform roughness upwards of 0.10 $0.12 \mathrm{~m}$ during peak conditions before the breakoff regime is entered and the ripples begin to flatten (Lyne et al., 1990a). Using flow conditions and observations in the southern MAB, Madsen et al. (1993) estimated a movable bed roughness ranging from 0.0002 to $0.0052 \mathrm{~m}$ during severe storms when the bed is expected to flatten. Based on these observations, a uniform value of $0.005 \mathrm{~m}$ was used in this study, which is a reasonable estimate during more extreme storms, when ripples flatten; during quiescent periods if relic bedforms are absent; and over muddy seabeds where ripples do not form; but may underestimate the roughness and hence the stress for sandy seabeds during moderate storm conditions when ripples develop. Because the calculated stress varies with $\ln \left(k_{b}\right)$, the relative influence of errors in the final calculations were reduced (Madsen et al., 1993).

\subsection{Wave model}

The wave model SWAN is a 3rd generation phase-averaged numerical wave model which conserves wave energy subject to generation, dissipation, and transformation processes and resolves spectral energy density over a range of user-specified frequencies and directions (Booij et al., 1999; Ris et al., 1999; The SWAN team, 2010a, 2010b). Although stress calculations were performed only over the spatial extent of the hydrodynamic model, SWAN was run over a larger area covering the U.S. East Coast, Gulf of Mexico, and western north Atlantic; this 5-km grid was originally developed for use with the Coupled OceanAtmosphere-Wave-Sediment Transport (COAWST) model system forecast (see Warner et al., 2010). This domain pushed the boundaries of the grid far from the region of interest to allow the wave spectrum (important in calculations of stress) to evolve before reaching the region of interest. The model was run for April 2010 using the default SWAN initial condition formulation for a non-stationary run to develop initial conditions for the one year study period (May 2010 to April 2011).

Significant wave height, dominant wave period, and wave direction were prescribed as SWAN TPAR format files on the model grid boundary with a spatial resolution of a boundary point every 25 grid cells using results from the NOAA Wavewatch III (Tolman, 2008) global multi-grid model, updated every $3 \mathrm{~h}$. A JONSWAP (JOint NOrth Sea WAve Project) spectral shape was assumed at these boundary points. Wind forcing was provided at 3-h resolution from the NOAA North American Mesoscale (NAM) model (12 km resolution) over its domain, with forcing at the most offshore portions of the grid (outside the NAM grid) provided by the NOAA Global Forecasting System (GFS) model at 0.5 degree resolution (Kalnay et al., 1990; Rogers et al., 1996). The SWAN directional resolution was $6^{\circ}$ ( 60 bins), determined via sensitivity analysis as the coarsest (and hence least computational expensive) resolution that did not result in the "GardenSprinkler Effect" (GSE), wherein swell traveling over large distances inaccurately disintegrates into non-continuous wave fields as a result of frequency and directional discretization (see Booij and Holthiujsen, 1987, for a discussion of the GSE). The minimum frequency bin should be set to a value less than 0.7 times the lowest expected peak frequency and the maximum frequency bin should be set at least 2.5-3 times the highest expected peak frequency expected (The SWAN Team, 2010b). In order to determine appropriate values, the peak periods from 43 NDBC buoys throughout the wave model domain were analyzed (when available) over the one year period of the study, yielding $297,533 \mathrm{~h}$ observations. The 99th and $1 \mathrm{st}$ percentiles of peak period were $15 \mathrm{~s}$ and $3 \mathrm{~s}$, corresponding to frequencies $(f)$ of $0.07 \mathrm{~Hz}$ and $0.33 \mathrm{~Hz}$, noting that these values may be biased by buoy limits of detection at high and low frequencies. The frequency range was therefore specified as $0.04-1 \mathrm{~Hz}$. SWAN was allowed to internally determine the frequency resolution $(\Delta f)$ as $\Delta f \approx 0.1 \mathrm{f}$ for best performance of the discrete interaction approximation (DIA) method of nonlinear 4-wave interactions, resulting in 34 frequency bins (The SWAN team, 2010b). Bottom friction calculations used the Madsen formulation with a uniform roughness length scale of $0.05 \mathrm{~m}$. This value was selected for the 
best comparison of model output and buoy observations within the domain, and did not correspond to physical roughness values or the bottom roughness used in stress calculations. Wind generation and whitecapping parameterizations followed the modified Komen approach prescribed by Rogers et al. (2003), which reduces inaccurate attenuation of swell energy by whitecapping. Wave model outputs of $u_{b r}, T_{b r}$, and $\phi_{w r}$ were output hourly and interpolated onto the ESPreSSO model grid.

Observations from ten full-spectra NDBC wave buoys (listed in Table 2, locations shown at http://www.ndbc.noaa.gov/maps/ Northeast.shtml and http://www.ndbc.noaa.gov/maps/Southeast. shtml) were used for wave model validation. Observations from all buoys were not available over the entire time period, and data from Station 44066 for January 2011, when the buoy was adrift but still reporting, were manually removed. Using the GM method and $k_{b}$ of $0.005 \mathrm{~m}$, surface and bottom wave parameters were calculated from buoy spectra and compared to modeled parameters at the same locations (Fig. 3, Table 1). The coefficient of determination $\left(R^{2}\right)$ for $u_{b r}(0.71)$ and WS (0.60) was lower than for significant wave height $\left(H_{S}, 0.85\right)$, indicating SWAN more precisely simulated $H_{S}$ than bottom wave parameters. The RMS error
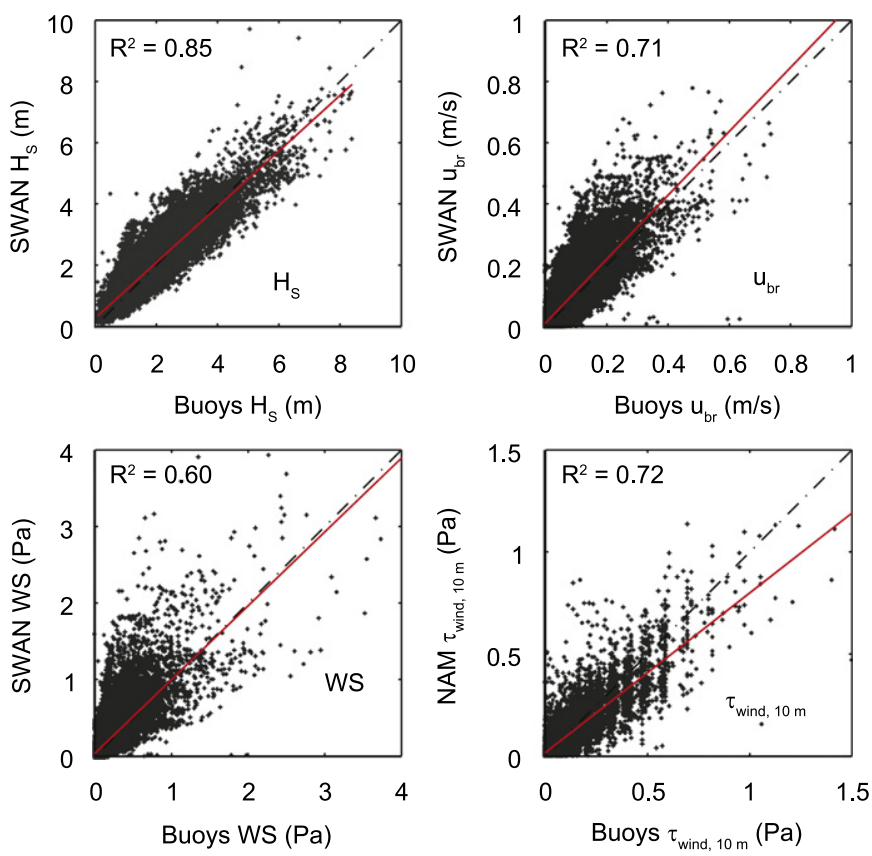

Fig. 3. Comparison of model output and buoy data for significant wave height $\left(H_{S}\right)$, bottom orbital velocity $\left(u_{b r}\right)$, bottom wave stress (WS), and wind stress at $10 \mathrm{~m}$ ( $\tau_{\text {wind, } 10 \mathrm{~m}}$ ), corresponding to values in Table 1 . Wave parameters are hourly output from the SWAN hindcast, wind is 3-h output from the NAM model used as input forcing. The red line is the best-fit linear regression through the data points, dashed black line is the 1:1 line on which data points would fall if the model results were identical to the observed data. (For interpretation of the references to colour in this figure legend, the reader is referred to the web version of this article.)

Table 1

Average over all buoys for slope of linear fit, coefficient of determination $\left(R^{2}\right)$, and root mean square error (RMS) for model-buoy comparison of significant wave height $\left(H_{S}\right)$, bottom orbital velocity $\left(u_{b r}\right)$, bottom wave stress (WS), and wind stress at $10 \mathrm{~m}\left(\tau_{\text {wind }}\right)$. Winds were from the NAM forecast used to force the hindcast, other parameters were calculated by SWAN.

\begin{tabular}{|c|c|c|c|c|c|c|c|c|c|c|c|}
\hline \multicolumn{3}{|c|}{$H_{s}(\mathrm{~m})$} & \multicolumn{3}{|c|}{$u_{b r}(\mathrm{~m} / \mathrm{s})$} & \multicolumn{3}{|c|}{ WS (Pa) } & \multicolumn{3}{|c|}{$\tau_{\text {wind, } 10 \mathrm{~m}}(\mathrm{~Pa})$} \\
\hline Slope & $R^{2}$ & RMS & Slope & $R^{2}$ & RMS & Slope & $R^{2}$ & RMS & Slope & $R^{2}$ & RMS \\
\hline 0.91 & 0.85 & 0.37 & 1.04 & 0.71 & 0.04 & 0.96 & 0.60 & 0.14 & 0.78 & 0.72 & 0.07 \\
\hline
\end{tabular}

in WS of 0.14 Pa was of concern for sediment mobility estimates, given that critical stress thresholds for some grain sizes are of order $0.1 \mathrm{~Pa}$. Increased errors in bottom wave parameters, even when $H_{S}$ was relatively accurate (mean RMS error of $0.37 \mathrm{~m}$ ), was a result of the greater sensitivity of $u_{b r}$ and $\tau_{\text {wave }}$ to the shape of the wave spectrum, particularly in the low-frequency part of the spectrum with longer-period waves that reach deeper into the water column. This difference underscored the need to use wave stress to validate wave models used for bottom stress calculations, rather than validating with significant wave height. Although the model has been parameterized to optimize prediction of WS, capability was limited in part by the accuracy and resolution of the NAM wind model forcing ( $3 \mathrm{~h}$ resolution, $12 \mathrm{~km}$ grid), which over the same time period has an overall $R^{2}$ of 0.72 and an RMS error of $0.07 \mathrm{~Pa}$.

To determine how WS prediction errors impacted the shelfwide stress characterizations, the mean, standard deviation (STD), and select percentiles (25th, 50th, 75th, and 95th PCT), were calculated from model stress and buoy WS at each station, both for the entire time period (Table 2, showing magnitude of error) and seasonally (not shown). In most cases, the error was order of magnitude $0.01 \mathrm{~Pa}$, with the largest errors found at buoys 44020 (Nantucket Sound) and 44070 (Rhode Island Sound), both of which are at locations not expected to be well resolved by the $5-\mathrm{km}$ grid. The magnitude of error increased at all buoys for the largest observed values (95th percentile). The relatively large error in STD indicated the model may not have captured some of the short time scale variability of the observations, which itself may be a function of both high frequency variability in the wave field and measurement noise. The weakest correlation between stress statistics calculated from model and buoy data occurred during late August/early September, when Hurricane Earl moved north along the coast of the MAB; the coarse spatial and temporal forcing of the wind field may not have fully captured the tropical cyclone, leading to errors in the model wave field. Overall, the comparison of statistical analyses of model results to buoy data indicated that the model was better at predicting WS climatology over the season/year than it was at capturing individual events, noting that errors are expected to be larger (1) during tropical cyclones when the wind field was poorly resolved, and (2) at locations where the topography and bathymetry were poorly resolved with a 5-km grid.

\subsection{Circulation model}

The ESPreSSO hydrodynamic model (http://www.myroms.org/ espresso/) has been operated by Rutgers University since October 2009 as a data-assimilative nowcast/forecast system for the MidAtlantic Regional Association Coastal Ocean Observing System (MARACOOS, http://maracoos.org/), part of the U.S. Integrated Ocean Observing System (http://www.ioos.gov). The underlying circulation model is the Regional Ocean Modeling System (ROMS; http://www. myroms.org), a finite-difference, hydrostatic, primitive equation ocean model that solves for the free surface elevation and three dimensional flow patterns, temperature, and salinity. Shchepetkin and McWilliams (2005, 2009a) describe the ROMS computational kernel in detail. Haidvogel et al. (2008), as corrected by Shchepetkin and McWilliams (2009b), give an overview of ROMS features and applications. There are numerous recent applications of ROMS in the MAB region (Wilkin et al., 2005; He and Wilkin, 2006; Wilkin, 2006; Chen and He, 2010; Zhang et al., 2009, 2010a) that demonstrate the model is capable of well representing circulation and dynamics at the scales of interest here.

The ESPreSSO configuration of ROMS has $5 \mathrm{~km}$ horizontal resolution and 36 layers in vertical terrain-following coordinates. Bathymetry and land-sea masking is from the National Geophysical Data 
Table 2

Comparison of WS from model output to values calculated from NDBC full-spectrum buoy data. Value in table is the magnitude of error (in Pa) between model and buoy. See http://www.ndbc.noaa.gov/maps/Northeast.shtml and http://www.ndbc.noaa.gov/maps/Southeast.shtml for buoy locations.

\begin{tabular}{|c|c|c|c|c|c|c|c|c|c|c|}
\hline Buoy & 41025 & 44008 & 44009 & 44014 & 44017 & 44020 & 44025 & 44065 & 44066 & 44070 \\
\hline Yearly Mean & 0.00 & 0.00 & 0.04 & 0.01 & 0.01 & 0.48 & 0.01 & 0.02 & 0.00 & 0.17 \\
\hline Yearly STD & 0.03 & 0.10 & 0.23 & 0.13 & 0.09 & 0.30 & 0.17 & 0.23 & 0.07 & 0.10 \\
\hline Yearly 50th PCT & 0.01 & 0.00 & 0.01 & 0.00 & 0.00 & 0.27 & 0.00 & 0.00 & 0.00 & 0.06 \\
\hline Yearly 75th PCT & 0.01 & 0.00 & 0.04 & 0.01 & 0.01 & 0.68 & 0.01 & 0.01 & 0.00 & 0.15 \\
\hline Yearly 95th PCT & 0.00 & 0.05 & 0.22 & 0.01 & 0.05 & 1.61 & 0.04 & 0.17 & 0.04 & 0.75 \\
\hline
\end{tabular}

Center (NGDC) Coastal Relief Model. The vertical turbulence closure is the $k-k l$ option of the Generalized Length Scale (GLS) formulation (Umlauf and Burchard, 2003; Warner et al., 2005). Air-sea fluxes of momentum and heat are computed using bulk formulae (Fairall et al., 2003) applied to ROMS ocean surface conditions and meteorological conditions (wind velocity, rain, downward long- and short-wave radiation, and marine boundary layer temperature, pressure, and relative humidity) from the same NAM forecast used to drive the SWAN wave hindcast. Ocean open boundary values are from a global forecast that uses the HYbrid Coordinate Ocean Model (HyCOM) with assimilation of satellite and in situ data (Chassignet et al., 2007, 2009) with the Navy Coupled Ocean Data Assimilation (NCODA) system (Hurlburt et al., 2008; Metzger et al., 2008). ESPreSSO river inflows are from daily U.S. Geological Survey (USGS) stream gauge data, and tidal harmonic boundary variability is determined from a regional tidal model (Mukai et al., 2002).

Output from the ESPreSSO forecast system is saved every $2 \mathrm{~h}$. Access to model results was made practical through the use of Thematic Real-time Environmental Distributed Data Services (THREDDS) technology, which allows subsets of large data sets to be accessed directly via Open-source Project for a Network Data Access Protocol (OPeNDAP) over the Internet from remote locations without transferring the entire multi-gigabyte model output. For this analysis, the circulation model output was interpolated to the same 1-h times as the wave model output.

The ESPreSSO data assimilation methodology closely follows that prototyped by Zhang et al. (2010b) for the inner MAB; the incremental strong constraint 4-dimensional variational (IS4DVar) approach (Moore et al., 2004; Powell et al., 2008) is used to optimally adjust the model state within a 3-day duration analysis interval that precedes each 72-h real-time forecast. The assimilation cycle is repeated daily (i.e., the 3-day analysis windows overlap) and the second $24 \mathrm{~h}$ of the analysis is retained as the "best estimate" of the ocean state for that day. In the ESPreSSO real-time configuration analyzed here, IS4DVAR applies increments only at the initial time of each 3-day analysis interval. This step change in model state generates somewhat unrealistic inertial oscillations, and for this reason the first $24 \mathrm{~h}$ of reanalysis is discarded in favor of the second day by which time the model physics restores a more consistent dynamical balance. It was these "best estimate" data that were analyzed here.

The data assimilated include surface currents from the MARACOOS HF-Radar (CODAR) network, sea surface temperature from satellite infrared (AVHRR) and microwave (AMSR-E) radiometers, and sea surface height anomalies from the Jason-2 altimeter satellite. In addition, a regional high-resolution climatology based on a 4-dimensional weighted least squares mapping of historical hydrographic data is assimilated to constrain biases in temperature and salinity introduced by the boundary conditions and/or internal model drift.

The modeled surface elevation was analyzed for the $M 2$ tide using T_TIDE (a MATLAB software package described in Pawlowicz et al. (2002), based on algorithms and FORTRAN code previously developed by Godin $(1972)$, and Foreman $(1977,1978)$ and compared to tidal

\section{Table 3}

Comparison of $M_{2}$ tidal current major and minor axis for model and observed data at 110 locations (Moody et al., 1984). Table includes the slope, intercept, and $R^{2}$ of the linear regression; and the RMS and mean error.

\begin{tabular}{lcc}
\hline & Major axis $(\mathrm{m} / \mathrm{s})$ & Minor axis $(\mathrm{m} / \mathrm{s})$ \\
\hline Slope & 1.01 & 1.04 \\
Intercept & 0.01 & -0.01 \\
$R^{2}$ & 0.90 & 0.91 \\
RMS & 0.05 & 0.02 \\
Mean error & -0.01 & -0.01 \\
\hline
\end{tabular}

analysis results of 50 observed records located within the model grid (Moody et al., 1984). Throughout the domain there is a systematic underprediction of the tidal range of approximately $0.05 \mathrm{~m}$.

The modeled currents were analyzed for the $M 2$ tide using T_TIDE and compared to tidal analysis results of 110 observed records of surface, mid-depth, and near-bottom currents (Moody et al., 1984) (Table 3). The RMS error for amplitude of major and minor axis of $M 2$ was $0.05 \mathrm{~m} / \mathrm{s}$ and $0.02 \mathrm{~m} / \mathrm{s}$, respectively, with slight bias toward underprediction of tidal currents (mean error for both major and minor axis of $-0.01 \mathrm{~m} / \mathrm{s}$ ). Assessment of mean annual flow shows qualitative agreement with the overall circulation patterns previously described (Section 2).

The 5-km resolution of the hydrodynamic model grid allowed a broad regional picture to be developed for the MAB, but limited analysis in some areas. Flow patterns in coastal estuaries (lower Chesapeake Bay, Delaware Bay, Long Island Sound) and in the narrow Hudson Shelf Valley were resolved by only a few grid cells. The model was density stratified and accordingly allowed the generation of internal tides. However, large-amplitude internal waves (LIW) of short wavelengths (e.g., "solitons" or "solitary wave trains") were not resolved. The hydrostatic approximation also eliminated some dynamics that govern generation, growth, and propagation of LIWs (Van Gastel et al., 2009), which have been routinely observed in the MAB during the summer months and may contribute to bottom stress and sediment transport (Butman et al., 1979, 2006).

\subsection{Bottom stress analysis}

The spatial variability of combined wave-current bottom stress (WCS) was characterized through the yearly median and half of the interpercentile range (hIPR, half of the difference between the 84 th percentile and the 16 th percentile). The hIPR normalized by the median value (NIPR, equivalent to the coefficient of variation for normal distributions) was calculated as a measure of normalized variance. The 95th percentile (e.g., the value exceeded by $5 \%$ of observations) of WCS was used as a measure of extreme values. The same set of statistics was also calculated by season, e.g., winter (December-February), spring (March-May), summer (June-August), and fall (SeptemberNovember). These and other yearly and seasonal statistics of stress and mobility are available online as ArcGIS files 
(U.S. Geological Survey Sea Floor Stress and Sediment Mobility Database, online at <http://woodshole.er.usgs.gov/project-pages/ mobility/index.html $>$ ).

The relative importance of waves, storm-driven currents, tidal currents, and persistent ocean currents in creating stress was statistically determined. The wave-stress in the absence of currents (WS) and the current stress in the absence of waves (CS) were calculated separately following Madsen (1994). To estimate the stress caused by tidal currents, a tidal velocity time series was produced using T_TIDE; stress calculated from this time series is called the TCS. This vector tidal time series was subtracted from the original vector current time series, leaving a non-tidal current time series that includes storm-driven currents (potentially significant in the MAB), a mean flow (typically $0.10 \mathrm{~m} / \mathrm{s}$ in the MAB), and persistent ocean currents (not expected to be significant in this region); stress was calculated for this current alone and called the NTCS. The relative contribution from each process was gauged by comparing the 95th percentile (which characterizes the contribution to large events) of each stress component (WS, TCS, NTCS). However, because tidal and non-tidal components may add or subtract based on direction and because bottom stress is a nonlinear function of current, the TCS and the NTSC scalars will not sum to be the total CS (e.g., stress calculated from hydrodynamic model current time series, which includes both tidal and non-tidal components). Similarly, because of nonlinear wave-current interaction, WS and CS calculated separately will not sum to the combined WCS. Analyzing the components of stress in this manner, however, allows for the relative magnitude of contributions from waves, tidal currents, and non-tidal currents to be assessed.

The influence of wind stress (hereafter referred to as "local winds") on wave and current generation was investigated by calculating for each grid cell the Pearson's correlation coefficient ( $r$, Rodgers and Nicewander, 1988) between local wind stress and the individual time series of WS, CS, and NTCS. Strong correlation indicated increases in bottom stress were well timed with increases in wind stress, and was not necessarily indicative of the magnitude of response. Areas of weak correlation between WS and local winds indicated the influence of non-local wind forcing (e.g., generating swell propagating into the domain), as opposed to locally generated wind waves. Correlation of NTCS and winds indicated locally wind driven currents.

Analysis of stress frequency was based on the spectral regionalization method of Hemer (2006). Spectral analysis (Welch, 1967) was used to determine the power (units of $\mathrm{Pa}^{2}$ ) frequency distribution of the WCS magnitude, with mean removed, at each grid point. Because the length of the time series was a single year, interannual variability was not resolved. The ratio of the total low-frequency (periods longer than $33 \mathrm{~h}$ ) energy to high frequency (periods shorter than $33 \mathrm{~h}$ ) energy was calculated as a measure of the relative contribution of these two bands. This frequency analysis may not always indicate the dominant stress process. For example, if the tidal ellipse is nearly circular, in the absence of other currents, the scalar current is nearly constant (the direction changes, but the magnitude does not), and thus will not appear in the spectral analysis at the tidal frequency. However, if superimposed on a mean current in a persistent direction, the rotation of a circular tide would modulate the scalar CS and create an oscillation that would appear in the high-frequency band. Another example is variations in the magnitude of stress associated with the spring/neap tidal cycle; although driven by the tides, these variations would appear in the low-frequency energy band. Spectral analysis may detect indirect tidal effects (such as phase-locked internal waves) or other high frequency oscillations.

Bed mobility was assessed at discrete locations by comparing skin friction to grain-size specific critical stress thresholds established using observed surficial sediment texture measurements (McMullen et al., 2011). The WCS as calculated previously was an estimate of the total force in the bottom boundary layer, based on a uniform roughness value of $0.005 \mathrm{~m}$ that would include a bedform contribution to roughness. Use of the WCS would overestimate the force acting on the sand grains to potentially induce resuspension and transport (Zhenlin, 1994). At each discrete location where sediment data were available, WCS was recalculated from wave and circulation model output using the GM method and a roughness $\left(k_{B}\right)$ based on the grain size distribution at that location.

The texture data included the distribution of sediment over grain size classes ranging from -5 to 11 phi. Bed mobility (referred to hereafter as "mobility") was established as the percentage of time the critical stress at each sample location was exceeded for that median grain size; a yearly mobility of $20 \%$ would indicate the bed was mobilized $20 \%$ of the year. To characterize frequency, the recurrence interval (RI) of mobility events (in units of day) was calculated for the winter and summer as the total length of the time series (in days) divided by the number of mobility events within the time period. A mobility event was identified by exceedance of the critical stress threshold, with no minimum duration or separation time between events. A RI of 10 days, for example, would indicate that, on average, the bed was mobilized every 10 days.

For sand grains, there is a positive correlation between critical stress and sediment grain size (Soulsby, 1997). However, mixed beds with both sand and fine-grained sediments may behave cohesively, increasing the critical stress (Panagiotopoulos et al., 1997; Torfs et al., 2000; Van Ledden et al., 2004). Texture observations were therefore first classified as cohesive or noncohesive based on whether the fraction of clay exceeded $7.5 \%$, chosen as the mean value from laboratory testing indicating the threshold to develop cohesive properties is between 5 and $10 \%$ clay (Van Ledden et al., 2004).

Critical stress thresholds for non-cohesive sediment mixtures were calculated from the critical Shields parameter, gravity (taken as $9.8 \mathrm{~m} / \mathrm{s}^{2}$ ), density of sediment (taken as $2650 \mathrm{~kg} / \mathrm{m}^{3}$ ), density of seawater (taken as $\left.1027 \mathrm{~kg} / \mathrm{m}^{3}\right)$, and median grain size $\left(d_{50}\right)$ following Soulsby (1997). The roughness used in calculating bottom stress at locations with a non-cohesive sediment distribution was also set to $d_{50}$.

For cohesive beds, particle cohesion strength, and hence critical stress, is a function of numerous interacting physical and biological factors that vary significantly in space and time (e.g., Roberts et al., 1998; Black et al., 2002; Widdows and Brinsley, 2002). Furthermore, as the bed erodes, the critical shear stress may increase as older, more resistant sediment layers are exposed (i.e., depth-limited erosion; e.g., Parchure and Mehta, 1985; Sanford and Maa, 2001; Van Ledden et al., 2004). Data did not exist to support a model of critical stress as a function of these varying properties, so a single value was used for all samples identified as cohesive. In situ, ex situ, and laboratory experimental measurements of critical stress in mixed beds range from 0.05 to 0.7 Pa (see Dickhudt et al., 2011, for a review). As the primary interest of this study was initiation of bed mobility, a value of 0.1 Pa was chosen. This value was consistent with an empirically determined critical stress of $0.08 \mathrm{~Pa}$ in the Mud Patch based on comparison of calculated stress to observed resuspension (Chang et al., 2001). The roughness used in the skin friction calculation for cohesive sediments was set to $62.5 \mu \mathrm{m}$ ( $4 \phi$, the boundary between very fine sand and coarse silt), which has a critical stress based on Soulsby (1997) of 0.1 Pa (the value used as a threshold for cohesive observations).

"Bed mobility" itself is subject to interpretation. Even at low stress values, some small fraction of the finest grains in the bed may be mobilized, whereas critical thresholds for resuspension (as opposed to motion) of a significant portion of the bed may be higher than the selected values. For both cohesive and 
non-cohesive beds, the critical stress thresholds described above have been chosen to approximate the threshold value for initiation of movement of a reasonable fraction of the bed, and prescribe a benchmark value for spatial and temporal comparison through the region.

\section{Results}

\subsection{Overall spatial variability}

The highest yearly median WCS (Fig. 4) was found over Nantucket Shoals and in a band of varying width along the coast. The lowest stresses occurred in deeper regions, including the outer continental shelf, the Hudson Shelf Valley, and the Mud Patch. Comparison of the stress distribution with surface sediment texture data (Fig. 2) showed that coarser sediments were typically found in regions of higher stress forcing, validating on a regional spatial scale the conceptual model of finer sediments being winnowed away in areas of stronger stress. The hIPR over the same period (Fig. 4) indicated that areas of strongest stress also had the highest variability. In contrast, the NIPR was largest in more quiescent regions offshore, indicative of infrequent large events relative to a lower average stress value. High values of NIPR were found over a broad area of the shelf extending from the center of the Mud Patch westward toward the HSV and along the outer shelf south of Delaware Bay. There was a local maximum over the HSV. The 95th percentile of stress (not shown) mirrored the overall spatial pattern of the median, with highest stress over Nantucket Shoals and in the coastal band. Seasonally, all of the non-tidal stress metrics had higher values and increased variability during the winter months, with widening of the high-stress coastal band and an increase in stress across the shelf (Figs. 5 and 6, shown for individual stress components).

\subsection{Physical processes}

Throughout most of the MAB, WS was the dominant process, except over Nantucket Shoals and in the sheltered coastal bays, where TCS was more significant (Figs. 5 and 6). The WS in shallower regions of the shelf was more correlated to the local winds (Fig. 7), since shorter-period wind-waves were capable of penetrating to shallow depths. Farther from shore, the correlation of WS with local winds was reduced, illustrating the relatively large influence of far-field generated swell. Variability in the alongshore indicated the central MAB (Chesapeake Bay north to the eastern edge of the Mud Patch) was more dominated by the influence of non-locally generated swell than the southern MAB (offshore of Cape Hatteras) or the northern MAB (Nantucket Shoals), where correlation was stronger with local winds. However, even within the southern MAB, correlation with local winds was only moderate $(r \sim 0.5)$. Although the $5-\mathrm{km}$ resolution of the model grid did not accurately resolve semi-enclosed areas like Chesapeake Bay and Delaware Bay, the relative isolation of these bays from the open ocean resulted in a strong correlation between the WS and local winds (Fig. 7).

The influence of wind-driven currents was observed in the correlation between CS and local winds (Fig. 7). Stress from storm-driven currents appeared as a strengthening of NTCS along the MAB shelf between summer and winter; storm-driven currents influenced stress out to water depths of about $40 \mathrm{~m}$. Even over tidally-dominated Nantucket Shoals, storm-driven currents were apparent in the correlation of NTCS with winds.

Spectral analysis of WCS (Fig. 8) showed relatively equal contribution of low- and high-frequency stress (ratio of approximately unity)

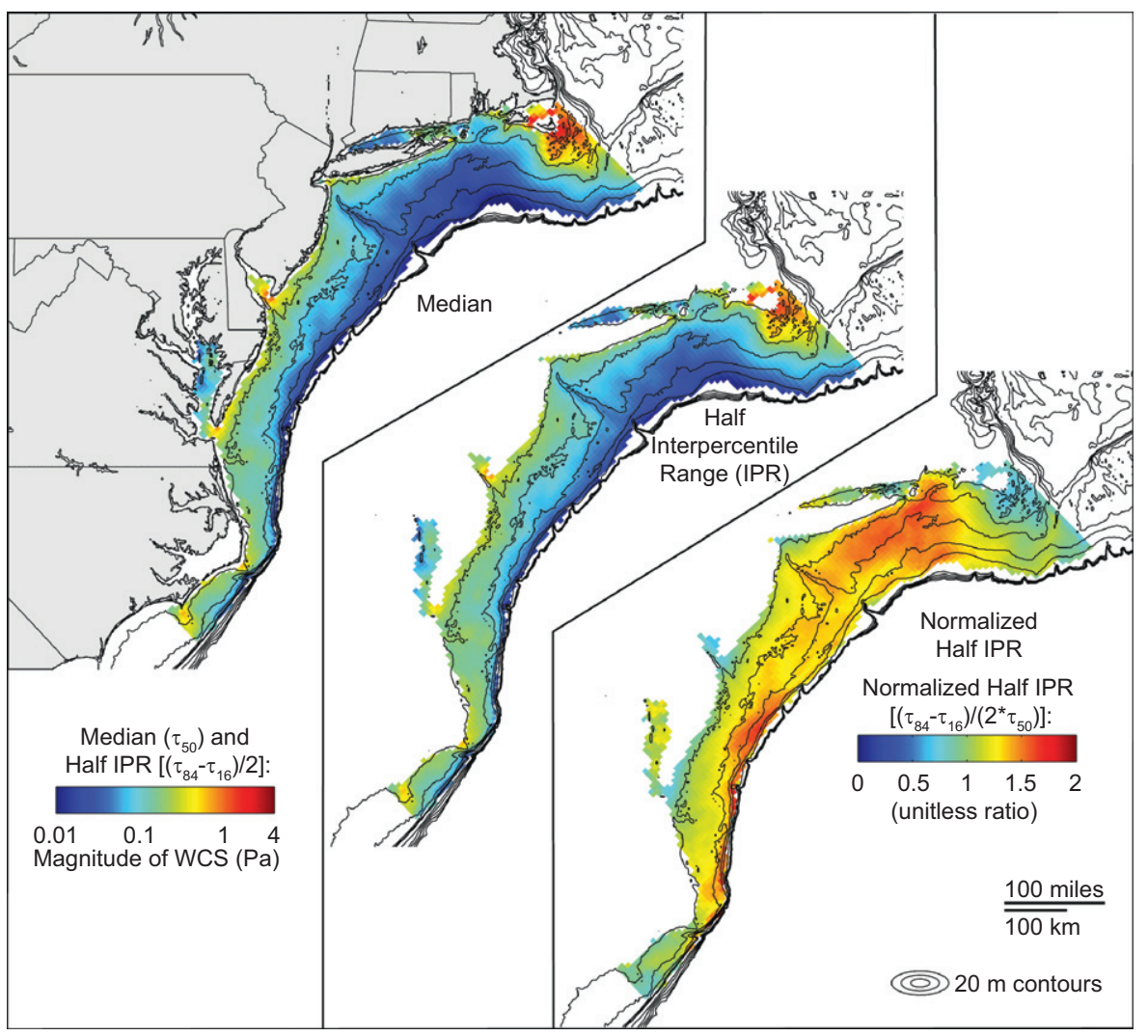

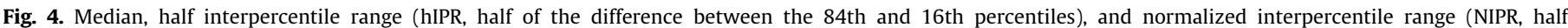
interpercentile range normalized by the median) of combined wave-current bottom stress for the period May $2010-$ April 2011 . 


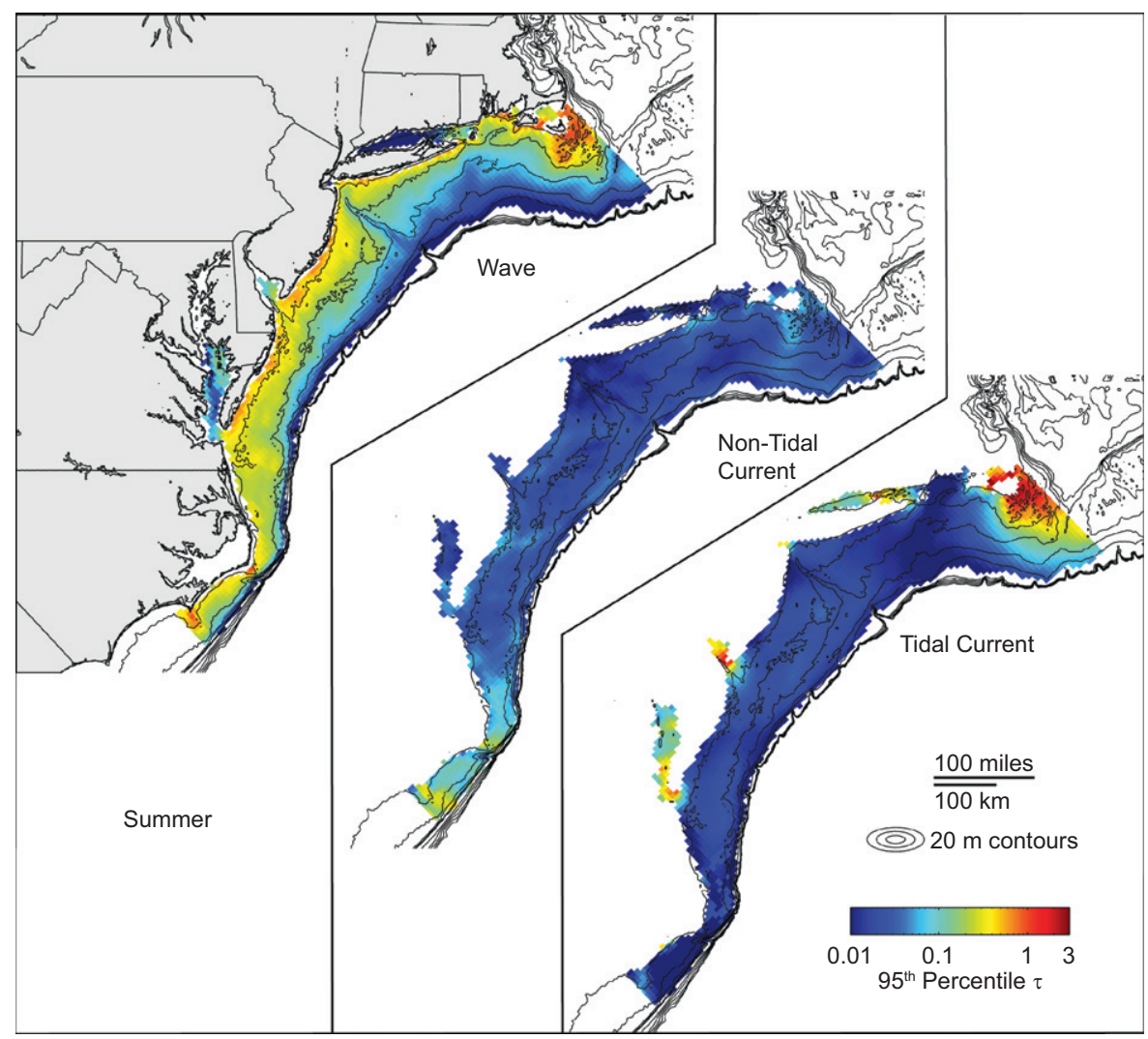

Fig. 5. Summer (June-August 2010) 95th percentile of bottom stress for caused by waves, non-tidal, and tidal currents separately, plotted on a log scale. See Section 3.4 for definition of these stress components.

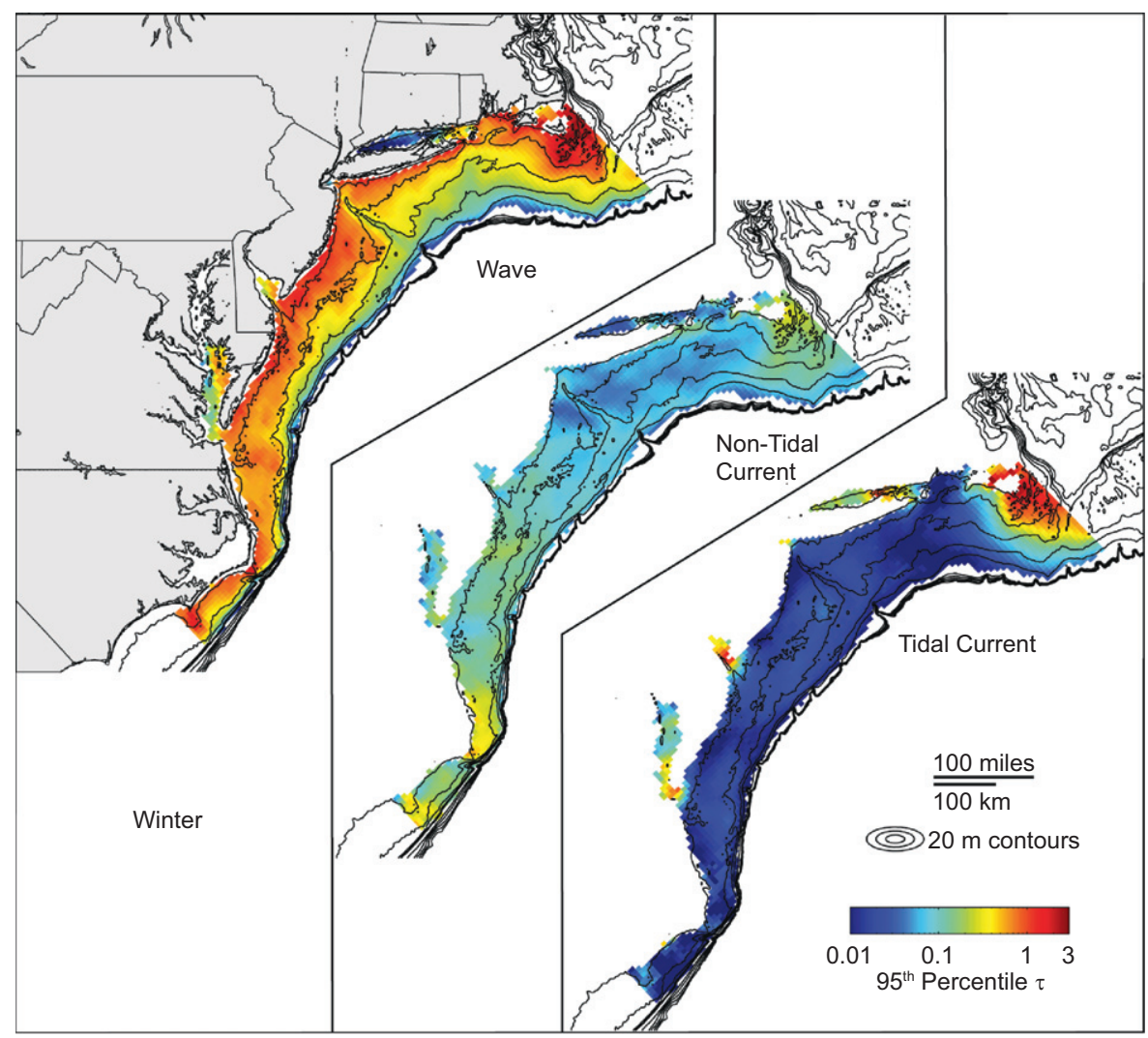

Fig. 6. Winter (December 2010-February 2011) 95th percentile of bottom stress caused by waves, non-tidal, and tidal currents separately, plotted on a log scale. See Section 3.4 for definition of these stress components. 


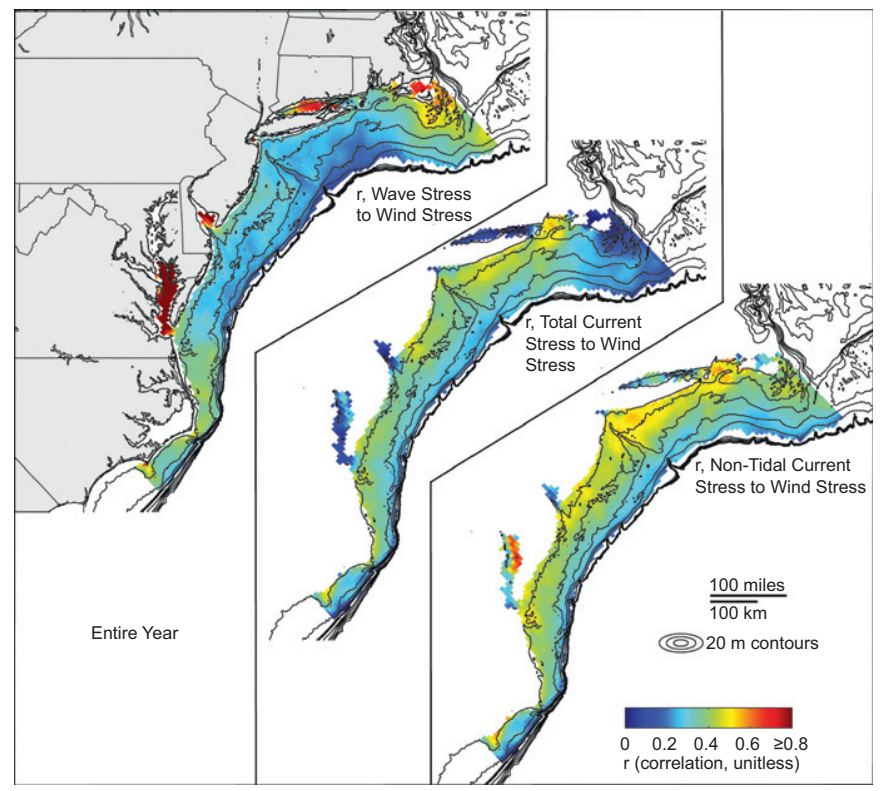

Fig. 7. Correlation $(r)$ of wind stress to wave stress, total current stress, and residual current stress (see Section 3.4 for definition of these stress components) over the one year time period May 2010-April 2011. The maximum plot scale is chosen as 0.8 to show variation on the shelf. The correlation between wind stress and wave stress is as high as 0.95 in parts of Chesapeake Bay.

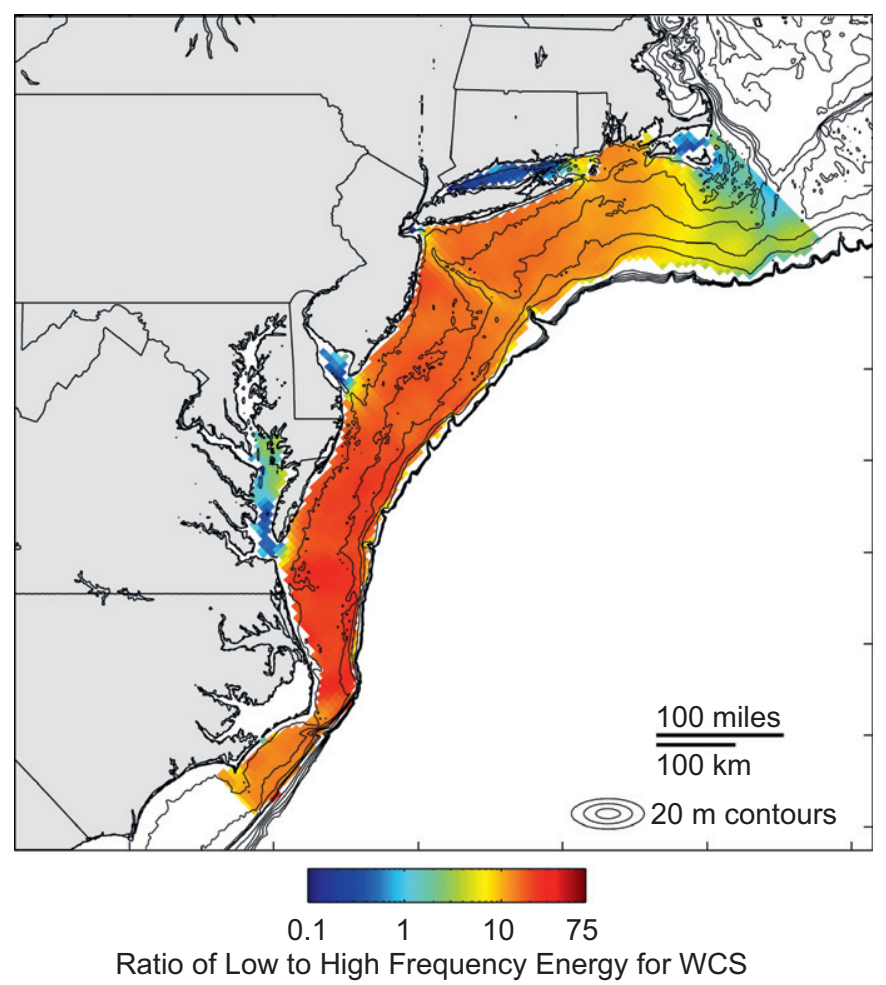

Fig. 8. Ratio of low frequency (periods longer than $33 \mathrm{~h}$ ) energy to high frequency (periods shorter than $33 \mathrm{~h}$ ) energy for combined wave-current stress over the one year time period May 2010-April 2011, plotted on a log scale.

over Nantucket Shoals, with low-frequency events becoming more dominant toward the south. The ratio of low to high-frequency energy was largest off of Cape Hatteras, where low-frequency energy was two orders of magnitude greater than high-frequency energy. Within sheltered estuaries, WCS was dominated by high-frequency events (in this case, tides).

\subsection{Geological processes}

The critical stress threshold for mobility over Nantucket Shoals and at the entrance of Chesapeake and Delaware Bays was exceeded over $75 \%$ of the year (Fig. 9). In the rest of the MAB, mobility was predominantly observed during the winter, with critical stress exceeded $8-20 \%$ of the season at depths less than $20-40 \mathrm{~m}$. In contrast, deeper areas and lower stress regions (such as over the fine-grained Mud Patch) were more quiescent, with $<5 \%$ mobility throughout the year. Mobility in the fall (September-November, 2010) and spring (March-May, 2011) was more similar to patterns observed in the winter (December 2010-February 2011) than in the summer (June-August, 2010), resulting in similarities between the yearly bed mobility and the pattern observed in the winter.

During the winter, the mobility RI at 20-40 m depth was less than 7 days, with daily events occurring over Nantucket Shoals and at the mouths of Chesapeake and Delaware Bays in both summer and winter (Fig. 10). At deeper depths (40-60 m), the RI in winter was 15-30 days, whereas in summer RI of that duration was confined to shallower depths in the coastal band (20-40 m). Few resuspension events were predicted at depths greater than $40 \mathrm{~m}$ during the summer, yielding a RI of 30 to more than 60 days.

\section{Discussion}

\subsection{Wave model}

Bottom wave stress results from the SWAN hindcast were compared to stress calculated from full spectra wave buoys located within the model domain. This comparison showed that an accurate description of the distribution of wave energy (the spectral shape) was critical to produce accurate estimates of bottom shear stress, which was particularly sensitive to energy in the longest period waves; comparisons of surface wave parameters such as significant wave height and peak period did not guarantee sufficient spectral accuracy for stress prediction. This result is important to consider in using numerical models for bottom stress prediction, given the known tendency for wave models to more accurately capture significant wave height than spectral shape (Gorrell et al., 2011). Comparison of buoy and model yearly and seasonal statistics of bottom wave stress indicated the model captured the wave stress climatology despite some inaccuracy in predicting stress during individual events.

\subsection{Stress characterization}

Over Nantucket Shoals, higher-frequency TCS was dominant and sufficient to induce daily sediment mobility. Although this result may seem intuitive because of the known strong tides over Nantucket Shoals, there were no field observations from which the frequency of mobility could be assessed. Despite the importance of tidal currents over Nantucket Shoals, the ratio of low to high frequency stress energy was approximately unity (Fig. 8). Although from a sediment transport perspective Nantucket Shoals was tidally dominated because tidal currents alone could induce bed mobility, storm-induced WS and NTCS for the MAB were also high over Nantucket Shoals (Figs. 5, 6).

Southwest of Nantucket Shoals lies the Mud Patch, where WS and CS weakened and the frequency of stress forcing and mobility decreased. The critical stress for resuspension was only exceeded by strong storm events that occured primarily in the winter, resulting in long gaps between resuspension events in the less energetic summer months and a virtually quiescent bed throughout most of the year. This persistent spatial pattern of a transition from strong stresses and daily mobility events over Nantucket 


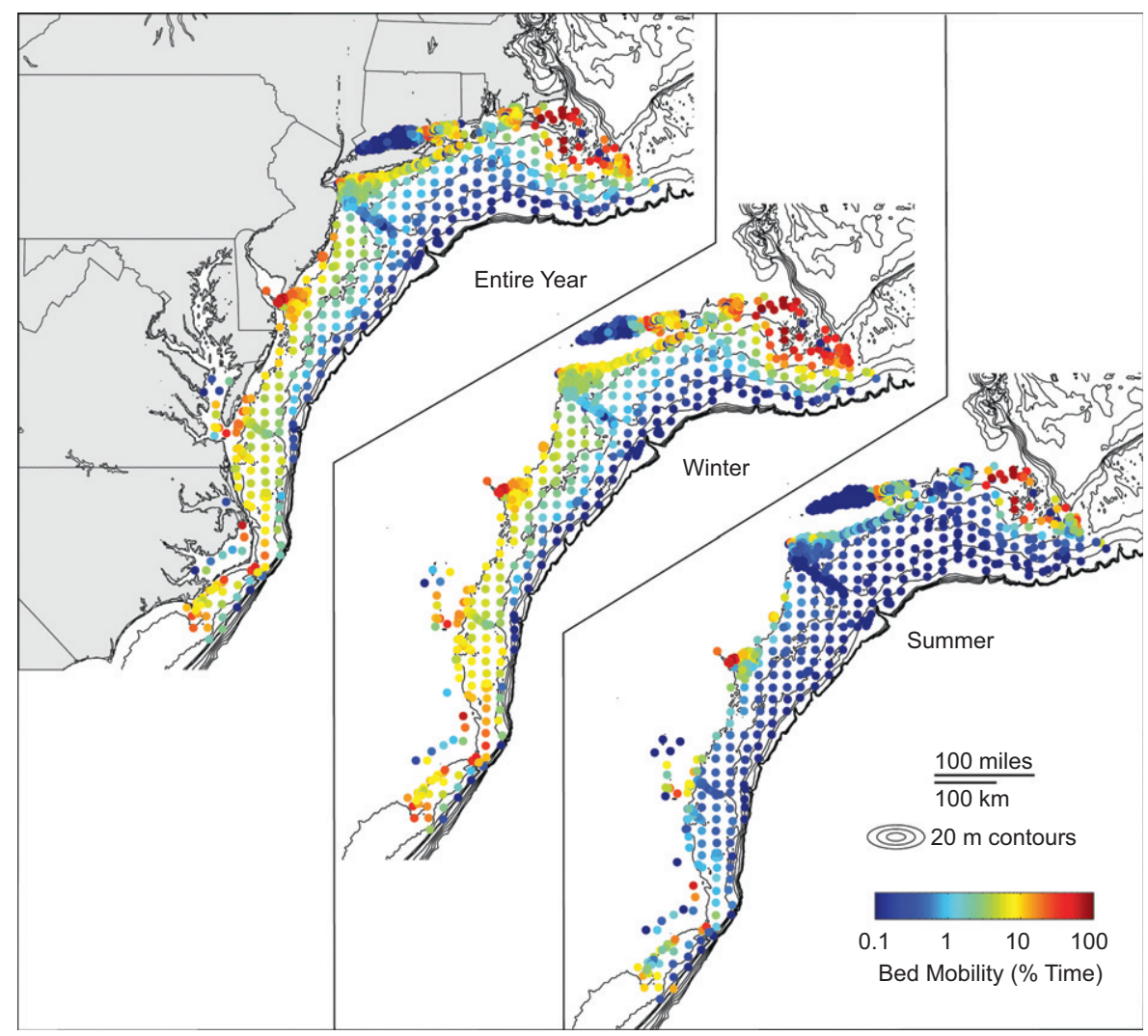

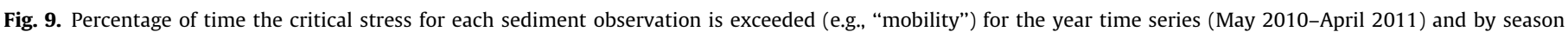
(December-February; June-August, plotted on a log scale.

Shoals to weaker stresses over the Mud Patch supports the hypothesis that sediments winnowed away from the higher stress regions to the northeast settle out of suspension here where the stress rapidly decreases (Twichell et al., 1981; Butman, 1987).

The northern MAB is divided from the southern MAB by the Hudson Shelf Valley (HSV) where increased depths reduce WS. The relative contribution of NTCS increased in winter with contributions from both mean flow and seasonal storm-driven currents that were reflected in the correlation between NTCS and local winds. This was consistent with limited observations of storm-driven flow in the HSV (Butman et al., 2003a; Harris et al., 2003), and demonstrated a persistent contribution in this region of storm-driven flow to sediment mobility. The results here again illustrated the need for careful consideration of statistical results. Although TCS in the HSV was weak compared to Nantucket Shoals, storm events occurred so infrequently that a relatively large fraction of energy was observed in high-frequency (tidal) bands. However, mobility analysis revealed that only stormdriven currents combined with mean flow were sufficient to induce sediment motion, so from a sediment transport perspective, the HSV was storm dominated.

South of the HSV toward Cape Hatteras, TCS weakened, and the analysis revealed a strengthening to the south in the dominance of low-frequency storm forcing. While WS was the dominant forcing mechanism throughout the southern MAB, the spatially variable correlation of WS with local winds suggested that the influence of far-field generated swell also varied spatially. While it had previously been observed during a single storm event at two point observations off Duck, North Carolina, that the longest period waves and highest stress forcing may lag the peak in wind stress forcing (Wright et al., 1994), the model results illuminated this phenomena as a persistent pattern in the MAB and documented spatial variability from north to south. Correlation between NTCS with local winds indicated that storm-driven currents have an appreciable influence on bottom shear stress.

Throughout the MAB, offshore regions near the shelf break were relatively quiescent, with weaker stress forcing unable to initiate significant mobility. Conversely, along the coast out to depths of $20-40 \mathrm{~m}$, a band of strong WS resulted in higher mobility of the coarser sediment texture located there, with critical stress values exceeded during the winter months at intervals of less than a week and during the summer months at intervals of 15-30 days. Mobility occurred at mid-shelf depths (60-80 m) with RI of 15-30 days during winter and monthly or more during summer. What prior point observations were available over limited temporal scales were consistent with these results; at 2 sites in the MAB at $\sim 60$ m depth Butman et al. (1979) observed 2 resuspension events over a 36 day winter period and 4 resuspension events over a 68 day winter period, respectively, for recurrence interval of 18 and 17 days.

\section{Summary}

The purpose of this project was to capitalize on advancements in numerical wave and circulation models to hindcast wavecurrent bottom shear stress, to develop methods to characterize stress, sediment mobility, and the underlying processes driving seasonal and regional variation, and to apply the methodology to the Middle Atlantic Bight to illuminate variations in bottom stress and sediment mobility in this region.

Wave current stress was calculated in the Middle Atlantic Bight using currents from the ESPreSSO operational forecast and a SWAN model wave hindcast for the period May 2010-April 2011. Comparison of the wave model results to full-spectrum observations from NDBC buoys demonstrated that errors in spectral wave shape 


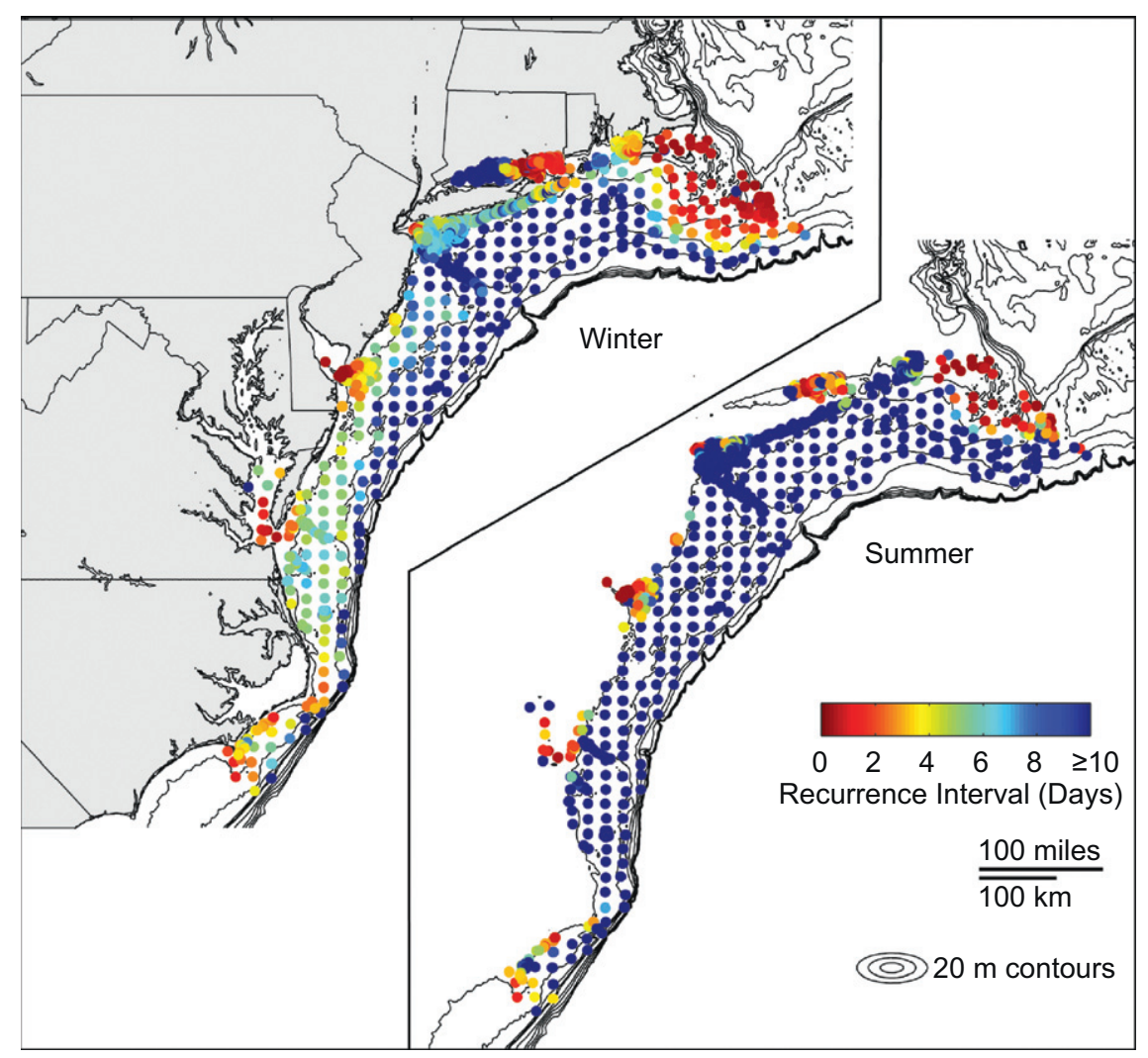

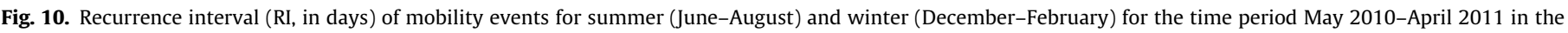
MAB; the maximum value displayed was chosen at 10 days to show the spatial and seasonal variability at moderate depths.

resulted in inaccuracies in bottom wave stress prediction, even though surface wave properties compared well, demonstrating that good agreement between modeled and observed surface wave properties does not guarantee good agreement in bottom stress.

Bottom stress and its principal forcing processes varied spatially and temporally in the Middle Atlantic Bight. Along the coast to depths of $30-40 \mathrm{~m}$, wind-waves and storm driven currents combined to produce sediment mobility events as frequently as weekly during winter months. Over Nantucket Shoals, despite strong contributions from both wave stress and storm-driven current stress, overall the combined stress was tidally dominated, and mobility analysis revealed thresholds for sediment mobility were exceeded over a tidal cycle. A strong gradient in shear stress to the southwest supports the hypothesis that fine grain sediments winnowed away in higher stress regions maintain the fine-grain "Mud Patch" to the southwest of Nantucket Shoals. Low-frequency storm events were dominant in the other regions of the MAB, and the relative importance increased toward the south reaching a maximum offshore of Cape Hatteras. Not surprisingly, the correlation between local wind stress and bottom stress decreased offshore as a result of the stronger influence of longer period waves on deeper depths; however, an alongshore variability was also found suggesting the central MAB is more influenced by swell from distant storms than the northern or southern $M A B$ where wind-waves have a stronger influence. Application of this analysis scheme to other continental shelf regions will likely identify a different mix of processes, spatial and temporal variability, and resultant sediment mobility.

\section{Acknowledgments}

John Warner and Brandy Armstrong developed the U.S. East Coast/Gulf of Mexico grid and some of the parameterizations used in the SWAN hindcast, and provided software code on which to base automated retrieval of forcing parameters. Page Valentine provided feedback on the applicability of stress characterizations, and an insightful review of this paper. Pat Dickhudt provided recommendations on critical stress thresholds for cohesive beds and Erin Twomey digitized the tables in the Moody et al. (1984) tidal atlas used for hydrodynamic validation. P.S. Dalyander was supported by the U.S. Geological Survey Mendenhall Research Fellowship Program.

\section{References}

Beardsley, R.C., Butman, B., 1974. Circulation on the New England continental shelf. Geophysical Research Letters 1, 181-184.

Black, K.S., Tolhurst, T.J., Paterson, D.M., Hagerthey, S.E., 2002. Working with natural cohesive sediments. Journal of Hydraulic Engineering 128, 2-8.

Böhm, E., Hopkins, T.S., Pietrafesa, L.J., Churchill, J.H., 2006. Continental slope sea level and flow variability induced by lateral movements of the Gulf stream in the Middle Atlantic Bight. Progress in Oceanography 70, 196-212.

Booij, N., Holthiujsen, L.H., 1987. Propagation of ocean waves in discrete spectral wave models. Journal of Computational Physics 68, 307-326.

Booij, N., Ris, R.C., Holthuijsen, L.H., 1999. A third-generation wave model for coastal regions 1. Model description and validation. Journal of Geophysical Research 104, 7649-7666.

Bothner, M.H., Parmenter, C.M., Milliman, J.D., 1981. Temporal and spatial variations in suspended matter in continental shelf and slope waters off the north-eastern United States. Estuarine, Coastal and Shelf Science 13, 213-234.

Butman, B., 1987. Physical processes causing surficial-sediment movement. In: Backus, R.H. (Ed.), Georges Bank. M.I.T. Press, Cambridge, MA, pp. 147-162, Chapter 13.

Butman, B., Alexander, P.S., Harris, C.K., Traykovski, P.A., ten Brink, M.B., Lightsom, F.S., Martini, M.A., 2003a. Oceanographic Observations in the Hudson Shelf Valley, December 1999-April 2000: Data Report. U.S. Geological Survey Open File Report 02-217, available online at 〈http://pubs.usgs.gov/of/2002/ of02-217/>.

Butman, B., Middleton, T.J., Thieler, E.R., Schwab, W.C., 2003b. Topography, Shaded Relief, and Backscatter Intensity in the Hudson Shelf Valley, Offshore of New York. U.S. Geological Survey Open File Report 03-372, 〈http://pubs.usgs.gov/ of $/ 2003 /$ of03-372/ $>$. 
Butman, B., Alexander, P.S., Scotti, A., Beardsley, R.C., Anderson, S.P., 2006. Large internal waves in Massachusetts Bay transport sediments offshore. Continental Shelf Research 26, 2029-2049.

Butman, B., Noble, M., Folger, D.W., 1979. Long-term observations of bottom current and bottom sediment movement on the mid-Atlantic continental shelf. Journal of Geophysical Research 84, 1187-1205.

Butman, B., Sherwood, C.R., Dalyander, P.S., 2008. Northeast storms ranked by wind stress and wave-generated bottom stress observed in Massachusetts Bay, 1990-2006. Continental Shelf Research 28, 1231-1245.

Chang, G.C., Dickey, T.D., Williams III, A.J., 2001. Sediment resuspension over a continental shelf during Hurricanes Edouard and Hortense. Journal of Geophysical Research 106, 9517-9531.

Chassignet, E., H. Hurlburt, H.E. Metzger, O.M. Smedstad, J. Cummings, G. Halliwell, R. Bleck, R. Baraille, A. Wallcraft, C. Lozano, H. Tolman, A. Srinivasan, S. Hankin, P. Cornillon, R. Weisberg, A. Barth, R. He, F. Werner, Wilkin, J., 2009 U.S. GODAE: Global Ocean Prediction with the HYbrid Coordinate Ocean Model (HYCOM), Ocean., 22, 64-75.

Chassignet, E.P., Hurlburt, H.E., Smedstad, O.M., Halliwell, G.R., Hogan, P.J., Wallcraft, A.J., Baraille, R., Bleck, R., 2007. The HYCOM (HYbrid Coordinate Ocean Model) data assimilative system. Journal of Marine Systems 65, 60-83.

Chen, K., He, R., 2010. Numerical Investigation of the Middle Atlantic Bight shelfbreak frontal circulation using a high-resolution ocean hindcast model. Journal of Physical Oceanography 40, 949-964.

Churchill, J.H., Wirick, C.D., Flagg, C.N., Pietrafesa, L.J., 1994. Sediment resuspension over the continental shelf east of the Delmarva Peninsula. Deep Sea Research Part II: Topical Studies in Oceanography 41, 341-363.

Clauser, F.H., 1956. The turbulent boundary layer. Advances in Applied Mathematics $4,1-51$.

Csanady, G.T., Churchill, J.H., Butman, B., 1988. Near-bottom currents over the continental slope in the Mid-Atlantic Bight. Continental Shelf Research 8 653-671.

Dickhudt, P.J., Friedrichs, C.T., Sanford, L.P., 2011. Mud matrix solids fraction and bed erodibility in the York River estuary, USA, and other muddy environments. Continental Shelf Research 31, S3-S13.

Dzwonkowski, B., Lipphardt Jr., B.L., Kohut, J.T., Yan, X., Garvine, R.W., 2010 Synoptic measurements of episodic offshore flow events in the central midAtlantic Bight. Continental Shelf Research 30, 1373-1386.

Fairall, C.W., Bradley, E.F., Hare, J.E., Grachev, A.A., Edson, J., 2003. Bulk parameterization of air-sea fluxes: updates and verification for the COARE algorithm. Journal of Climate 16, 571-591.

Foreman, M.G.G., 1977. Manual for Tidal Heights Analysis and Prediction. Pacific Marine Science Report 77-10, Institute of Ocean Sciences, Patricia Bay, Sidney, BC.

Foreman, M.G.G., 1978. Manual for Tidal Currents Analysis and Prediction. Pacific Marine Science Report 78-6, Institute of Ocean Sciences, Patricia Bay, Sidney, BC.

Friedrichs, C.T., Wright, L.D., Hepworth, D.A., Kim, S.C., 2000. Bottom-boundarylayer processes associated with fine sediment accumulation in coastal seas and bays. Continental Shelf Research 20, 807-841.

Glenn, S.M., 1983. A Continental Shelf Bottom Boundary Layer Model: The Effects of Waves, Currents, and a Moveable Bed. Dissertation, Massachusetts Institute of Technology and Woods Hole Oceanographic Institution, Cambridge, MA $237 \mathrm{pp}$.

Glenn, S.M., Grant, W.D., 1987. A suspended sediment stratification correction for combined wave and current flows. Journal of Geophysical Research 92 8244-8264.

Godin, G., 1972. The Analysis of Tides. University of Toronto Press, Toronto.

Gorrell, L., Raubenheimer, B., Elgar, S., Guza, R.T., 2011. SWAN predictions of waves observed in shallow water onshore of complex bathymetry. Coastal Engineering $58,510-516$.

Goud, M.R., 1987. Prediction of Continental Shelf Sediment Transport Using a Theoretical Model of the Wave-Current Boundary Layer. Dissertation, Massachusetts Institute of Technology and Woods Hole Oceanographic Institution, Cambridge, MA $211 \mathrm{pp}$.

Grant, W.D., Madsen, O.S., 1986. The continental-shelf bottom boundary-layer Annual Review of Fluid Mechanics 18, 265-305.

Grant, W.D., Madsen, O.S., 1982. Movable bed roughness in unsteady oscillatory flow. Journal of Geophysical Research 87, 469-481.

Grant, W.D., Madsen, O.S., 1979. Combined wave and current interaction with a rough bottom. Journal of Geophysical Research 84, 1797-1808.

Haidvogel, D.B., Arango, H., Budgell, W.P., Cornuelle, B.D., Curchitser, E., Di Lorenzo, E., Fennel, K., Geyer, W.R., Hermann, A.J., Lanerolle, L., Levin, J., McWilliams, J.C., Miller, A.J., Moore, A.M., Powell, T.M., Shchepetkin, A.F. Sherwood, C.R., Signell, R.P., Warner, J.C., Wilkin, J., 2008. Ocean forecasting in terrain-following coordinates: formulation and skill assessment of the Regional Ocean Modeling System. Journal of Computational Physics 227, 3595-3624.

Harris, C.K., Butman, B., Traykovski, P., 2003. Winter-time circulation and sediment transport in the Hudson Shelf Valley. Continental Shelf Research 23 , 801-820.

Harris, P.T., Coleman, R., 1998. Estimating global shelf sediment mobility due to swell waves. Marine Geology 150, 171-177.

He, R., Wilkin, J., 2006. Barotropic tides on the southeast New England shelf: a view from a hybrid data assimilative modeling approach. Journal of Geophysical Research 111, C08002.

Hemer, M.A., 2006. The magnitude and frequency of combined flow bed shear stress as a measure of exposure on the Australian continental shelf. Continental Shelf Research 26, 1258-1280.
Holmedal, L.E., Myrhaug, D., Rue, H., 2003. The sea bed boundary layer under random waves plus current. Continental Shelf Research 23, 717-750.

Holthuijsen, L.H., Booij, N., Ris, R.C., 1993. A spectral wave model for the coastal zone, Proceedings 2nd Int. Symp. Ocean Wave Meas. Anal., pp. 630-641.

Hurlburt, H.E., Chassignet, E.P., Cummings, J.A., Kara, A.B., Metzger, E.J., Shriver, J.F., Smedstad, O.M., Wallcraft, A.J., Barron, C.N., 2008. Eddy-resolving global ocean prediction. In: Hecht, M., Hasumi, H. (Eds.), Ocean Modeling in an Eddying Regime, Geophys. Monograph 177. American Geophysical Union, Washington, D.C., Model output access at last access 9/7/2011.

Kalnay, M., Kanamitsu, M., Baker, W.D., 1990. Global numerical weather prediction at the National Meteorological Center. Bulletin of the American Meteorological Society 71, 1410-1428, Model output access at last access 9/7/2011.

Keen, T.R., Glenn, S.M., 1995. A coupled hydrodynamic-bottom boundary layer model of storm and tidal flow in the Middle Atlantic Bight of North America. Journal of Physical Oceanography 25, 391-406.

Lentz, S.J., 2008a. Observations and a model of the mean circulation over the Middle Atlantic Bight continental shelf. Journal of Physical Oceanography 38 1203-1221.

Lentz, S.J., 2008b. Seasonal variations in the circulation over the Middle Atlantic Bight continental shelf. Journal of Physical Oceanography 38, 1486-1500.

Lyne, V.D., Butman, B., Grant, W.D., 1990a. Sediment movement along the U.S. east coast continental shelf-I. Estimates of bottom stress using the Grant-Madsen model and near-bottom wave and current measurements. Continental Shelf Research 10, 397-428.

Lyne, V.D., Butman, B., Grant, W.D., 1990b. Sediment movement along the U.S. east coast continental shelf-II. Modelling suspended sediment concentration and transport rate during storms. Continental Shelf Research 10, 429-460.

Madsen, O.S., 1994. Spectral wave-current bottom boundary layer flows, Proceedings 24th Conf. Coastal Eng., pp. 384-398.

Madsen, O.S., Wright, L.D., Boon, J.D., Chisholm, T.A., 1993. Wind stress, bed roughness and sediment suspension on the inner shelf during an extreme storm event. Continental Shelf Research 13, 1303-1324.

Madsen, O.S., Poon, Y., Graber, H.C., 1988. Spectral wave attenuation by bottom friction: theory, Proceedings 21st Int. Conf. Coast. Eng., pp. 492-504.

McMullen, K.Y., Paskevich, V.F., Poppe, L.J., 2011. GIS data catalog (version 2.2), in: Poppe, L.J., Williams, S.J. and Paskevich, V.F. (Eds.), 2005, USGS East-Coast Sediment Analysis: Procedures, Database, and GIS Data, U.S. Geological Survey Open-File Report 2005-1001, available online at <http://woodshole.er.usgs. gov/openfile/of2005-1001/htmldocs/datacatlog.htm $\rangle$.

Metzger, E.J., Smedstad, O.M., Thoppil, P., Hurlburt, H.E., Wallcraft, A.J., Franklin, D.S., Shriver, J.F., Smedstad, L.F., 2008. Validation Test Report for Global Ocean Prediction System V3.0-1/12 HYCOM/NCODEA: Phase I, NRL Memo. Report, NRL/MR/7320-09-9148.

Moody, J.A., Butman, B., Beardsley, B., Brown, W.S., Daifuku, P., Irish, J.D., Mayer D.A., Mofjeld, H.O., Petrie, B., Ramp, S., Smith, P., Wright, W.R., 1984. Atlas of tidal elevation and current observations on the Northeast American continental shelf and slope. U.S. Geological Survey Bulletin 1611, 122.

Moore, A.M., Arango, H.G., Di Lorenzo, E., Cornuelle, B.D., Miller, A.J., Neilson, D.J., 2004. A comprehensive ocean prediction and analysis system based on the tangent linear and adjoint of a regional ocean model. Ocean Modelling 7, 227-258.

Mukai, A.Y., Westerink, J.J., Luettich Jr., R.A., Mark, D., 2002. Eastcoast 2001, A Tidal Constituent Database for Western North Atlantic, Gulf of Mexico, and Caribbean Sea. ERDC/CHL TR-02-24, U.S. Army Corps of Engineers, Washington, D.C. Model output access at $<$ http://www.unc.edu/ims/ccats/tides/tides. htm $>$, last accessed 9/7/2011.

Nikuradse, J., 1933. Stromungsgesetz in Rauhren Rohren, Vdi-Forschlungsheft 361. Trans. National Advisory Commission for Aeronautics, 1950. Laws of Flow in Rough Pipes. NACA Technical Memo 1292, Washington, DC.

Panagiotopoulos, I., Voulgaris, G., Collins, M.B., 1997. The influence of clay on the threshold of movement of fine sandy beds. Coastal Engineering 32, 19-43.

Parchure, T.M., Mehta, A.J., 1985. Erosion of soft cohesive sediment deposits. Journal of Hydraulic Engineering 111, 1308-1326.

Pawlowicz, R., Beardsley, B., Lentz, S., 2002. Classical tidal harmonic analysis including error estimates in MATLAB using T_TIDE. Computers \& Geosciences 28, 929-937.

Porter-Smith, R., Harris, P.T., Andersen, O.B., Coleman, R., Greenslade, D., Jenkins, C.J., 2004. Classification of the Australian continental shelf based on predicted sediment threshold exceedance from tidal currents and swell waves. Marine Geology 211, 1-20.

Powell, B.S., Arango, H.G., Moore, A.M., Di Lorenzo, E., Milliff, R.F., Foley, D., 2008. 4DVAR data assimilation in the Intra-Americas Sea with the Regional Ocean Modeling System (ROMS). Ocean Modelling 25, 173-188.

Reid, J.M., Reid, J.A., Jenkins, C.J., Hastings, M.E., Williams, S.J., Poppe, L.J., 2005. uSSEABED: Atlantic coast offshore surficial sediment data release. U.S. Geological Survey Data Series 118, version 1.0, available online at $\langle$ http://pubs.usgs. gov/ds/2005/118/images/pdf/report.pdf $>$.

Ris, R.C., Holthuijsen, L.H., Booij, N., 1999. A third-generation wave model for coastal regions 2. Verification. Journal of Geophysical Research 104, 7667-7681.

Roberts, J., Jepsen, R., Gotthard, D., Lick, W., 1998. Effects of particle size and bulk density on erosion of quartz particles. Journal of Hydraulic Engineering 124, 1261-1267.

Rodgers, J.L., Nicewander, W.A., 1988. Thirteen ways to look at the correlation coefficient. The American Statistical 42, 59-66.

Rogers, E., Black, T.L., Deaven, D.G., DiMego, G.J., 1996. Changes to the operational "early" Eta analysis/forecast system at the National Centers for environmental 
prediction. Weather and Forecasting 11, 391-413, Model output access at last accessed 9/7/2011.

Rogers, W.E., Hwang, P.A., Wang, D.W., 2003. Investigation of wave growth and decay in the SWAN Model: three regional-scale applications. Journal of Physical Oceanography 33, 366-389.

Sanford, L.P., Maa, J.P.-Y., 2001. A unified erosion formulation for fine sediments. Marine Geology 179, 9-23.

Sanford, T.B., Lien, R.-C., 1999. Turbulent properties in a homogenous tidal bottom boundary layer. Journal of Geophysical Research 104, 1245-1257.

Shchepetkin, A.F., McWilliams, J.C., 2005. The regional oceanic modeling system (ROMS): a split-explicit, free-surface, topography-following-coordinate oceanic model. Ocean Modelling 9, 347-404.

Shchepetkin, A., McWilliams, J.C., 2009a. Computational kernel algorithms for fine-scale, multi-process, long-term oceanic simulations, in: R. Temam, J. Tribbia (Guest Eds.), Computational Methods for the Ocean and the Atmosphere, P.G. Ciarlet (Ed.), Handbook of Numerical Analysis, vol. XIV, pp. 119182, Elsevier Science.

Shchepetkin, A., McWilliams, J.C., 2009b. Correction and commentary for Ocean forecasting in terrain-following coordinates: formulation and skill assessment of the Regional Ocean Modeling System by Haidvogel et al. Journal of Computational Physics 227, 3595-3624, J. Comput. Phys. 228, 8985-9000.

Sherwood, C.R., Lacy, J.R., Voulgaris, G., 2006. Shear velocity estimates on the inner shelf off Grays Harbor, Washington, USA. Continental Shelf Research 26, 1995-2018.

Shi, J.Z., Wang, Y., 2008. The vertical structure of combined wave-current flow. Ocean Engineering 35, 174-181.

Shroyer, E.L., Moum, J.N., Nash, J.D., 2010. Energy transformations and dissipation of nonlinear internal waves over New Jersey's continental shelf. Nonlinear Processes in Geophysics 17, 345-360.

Soulsby, R.L., Hamm, L., Klopman, G., Myrhaug, D., Simons, R.R., Thomas, G.P., 1993. Wave-current interaction within and outside the bottom boundary layer. Coastal Engineering 21, 41-69.

Soulsby, R., 1997. Dynamics of Marine Sands, a Manual for Practical Applications. Thomas Telford Publications, London.

The SWAN team, 2010a. SWAN: Scientific and Technical Documentation, SWAN Cycle III Version 40.81. Delft University of Technology, Delft, The Netherlands.

The SWAN team, 2010b. SWAN: User Manual, SWAN Cycle III Version 40.81. Delft University of Technology, Delft, The Netherlands.

Tolman, H.L., 2008. A mosaic approach to wind wave modeling. Ocean Modelling 25, 35-47, Model output access at last accessed 9/7/2011.

Torfs, H., Jiang, J., Mehta, A.J., 2000. Assessment of the erodibility of fine/coarse sediment mixtures. Proceedings of Marine Science 3, 109-123.

Twichell, D.C., McClennen, C.E., Butman, B., 1981. Morphology and processes associated with the accumulation of the fine-grained sediment deposit on the southern New England shelf. Journal of Sedimentary Research 51, 269-280.
Umlauf, L., Burchard, H., 2003. A generic length-scale equation for geophysical turbulence models. Journal of Marine Research 61, 235-265.

U.S. Department of Commerce, 2006. National Oceanic and Atmospheric Administration, National Geophysical Data Center, 2-minute Gridded Global Relief Data (ETOPO2v2). 〈http://www.ngdc.noaa.gov/mgg/fliers/06mgg01.html 〉, last accessed 9/7/2011.

Van Gastel, P., Ivey, G.N., Meuleners, M.J., Antenucci, J.P., Fringer, O., 2009. The variability of the large-amplitude internal wave field on the Australian North West Shelf. Continental Shelf Research 29, 1373-1383.

Van Ledden, M., van Kesteren, W.G.M., Winterwerp, J.C., 2004. A conceptual framework for the erosion behaviour of sand-mud mixtures. Continental Shelf Research 24, 1-11.

Warner, J., Sherwood, C., Arango, H., Signell, R., 2005. Performance of four turbulence closure models implemented using a generic length scale method. Ocean Modelling 8, 81-113.

Warner, J.C., Armstrong, B., He, R., Zambon, J.B., 2010. Development of a Coupled Ocean-Atmosphere-Wave-Sediment Transport (COAWST) Modeling System. Ocean Modelling 35, 230-244.

Welch, P.D., 1967. The use of fast fourier transform for the estimation of power spectra: a method based on time averaging over short, modified periodograms. IEEE Transactions on Audio and Electroacoustics 15, 70-73.

Wibert, P.L., Sherwood, C.R., 2008. Calculating wave-generated bottom orbital velocities from surface wave parameters. Computers \& Geosciences 34, 1243-1262.

Widdows, J., Brinsley, M., 2002. Impact of biotic and abiotic processes on sediment dynamics and the consequences to the structure and functioning of the intertidal zone. Journal of Sea Research 48, 143-156.

Wilkin, J.L., Arango, H.G., Haidvogel, D.B., Lichtenwalner, C.S., Durski, S.M. Hedstrom, K.S., 2005. A Regional Ocean Modeling System for the long-term ecosystem observatory. Journal of Geophysical Research 110, C06S91.

Wilkin, J., 2006. Modeling the summertime heat budget and circulation of southeast New England shelf waters. Journal of Physical Oceanography 36, 1997-2011.

Wright, L.D., Xu, J.P., Madsen, O.S., 1994. Across-shelf benthic transports on the inner shelf of the Middle Atlantic Bight during the "Halloween storm" of 1991 Marine Geology 118, 61-77.

Zhang, W., Wilkin, J., Chant, R., 2009. Modeling the pathways and mean dynamics of river plume dispersal in New York Bight. Journal of Physical Oceanography 39, 1167-1183.

Zhang, W., Wilkin, J., Schofield, O., 2010a. Simulation of water age and residence time in the New York Bight. Journal of Physical Oceanography 40, 965-982.

Zhang, W., Wilkin, J., Arango, H., 2010b. Towards an integrated observation and modeling system in the New York Bight using variational methods, Part I: 4DVAR Data Assimilation. Ocean Modelling 35, 119-133.

Zhenlin, Li, M., 1994. Direct skin friction measurements and stress partitioning over movable sand ripples. Journal of Geophysical Research 99, 791-799. 